\title{
Foxconned Labour as the Dark Side of the Information Age: Working Conditions at Apple's Contract Manufacturers in China.
}

\author{
Marisol Sandoval
}

City University London, UK, marisol.sandoval.1@city.ac.uk

\begin{abstract}
Apple is one of the most dominant and most admired computer companies in the world. But hidden behind the clean surface of Apple's advanced gadgets lies a dirty world of work. This paper focuses on the dark side of the information age by looking at working conditions in the workshops of Apple's contract manufacturers in China. For this purpose I suggest a systematic model of working conditions that can be used for assessing and comparing work in different industries. Departing from Karl Marx's circuit of capital it identifies elements that shape working conditions throughout the capital accumulation process including productive forces, relations of production, the production process, products, and labour legislation. Subsequently I apply this model to the realm of electronics manufacturing. Based on research conducted by corporate watchdogs this paper provides detailed insights into the work and life reality of workers in Apple's first tier supplier factories. An analysis of Apple's response to labour rights allegations furthermore reveals three ideological patterns that rather obscure existing problems than offering viable solutions.
\end{abstract}

Keywords: Apple, Foxconn, Working Conditions, Digital Labour, Electronics Manufacturing, Value Chain, China, Political Economy of ICTs, Corporate Watchdog

Information and Communication Technologies (ICTs) have played a double role in the restructuring of capitalism since the 1970s. On the one hand they enable fast transnational communication that is needed for organising international markets and value chains. On the other hand the production of these technologies is itself based on an international supply network (Dyer-Witheford 2014; Hong 2011, 9). Nick Dyer-Witheford therefore describes the value chain as "the dirty secret of the digital revolution" (Dyer-Witheford 2014). Part of this "dirty secret" is that "the global information economy is built in part on the backs of tens of millions Chinese industrial workers" (Zhao and Duffy 2008, 229).

The clean, immaculate and advanced surface of modern computer products hides the dirty reality of their production process. Concepts such as "digital sublime" (Mosco 2004) or "technological sublime" (Maxwell and Miller 2012, 7) suggest that certain myths and utopian ideals are attached to media and communication technologies. Maxwell and Miller argue that this has as a consequence that the "way technology is experienced in daily life is far removed from the physical work and material resources that go into it" (Maxwell and Miller 2012, 7).

The tendency even of critical scholarship to focus on how the usage of ICTs as production technologies is transforming work, perpetuates the technological sublime rather than unmasking it. In this vein Hardt and Negri for example highlight that the "contemporary scene of labour and production [...] is being transformed under the hegemony of immaterial labor, that is labor that produces immaterial products, such as information, knowledge, ideas, images, relationships, and affects" (Hardt and Negri 2004, 65). Even if they recognize that the rise of "immaterial labour" does not lead to the disappearance of industrial labour the term tends to mystify the actual impact of ICTs and digital technologies on work and workers on a global scale. Before and after ICTs serve as the instruments of the mental labour of software developers, journalists, designers new media workers, prosumers etc. their production and disposal is shaped by various forms of manual work such as the extraction of minerals, the assembly of components into the final product and the waste work needed for their disposal. 
Conceptualizing digital labour only as mental and immaterial labour misrepresents the character of ICTs and digital technologies as it tends to downplay the physical and manual labour that goes into them.

The notion of immaterial labour only focuses on the bright side of the expansion of communication, interaction and knowledge, while leaving its dirty counterpart in the dark. What is rather needed is demystification by fostering "greater transparency in working conditions throughout the ICT/CE supply chain" in order to shed light on the work and life realities of "workers who disappear in the twilight zone of the technological sublime" (Maxwell and Miller 2012, 108). As Vincent Mosco argues, only if computer technologies "cease to be sublime icons of mythology [...] they can become important forces for social and economic change" (Mosco 2004, 6).

This paper contributes to this task of demystification as it looks at the working conditions in Chinese assembly plants of one of the world's most dominant and most admired computer companies: Apple Inc. Studying Apple is important because the company represents both the mental and the manual side of digital labour: For many years Apple's products have been known as the preferred digital production technologies for the knowledge work of designers, journalists, artists and new media workers. iPhone, iPod and Co are symbols for technological progress that enables unprecedented levels of co-creation and sharing of knowledge, images and affects as well as interaction, communication, co-operation etc. At the same time during the past years Apple has become an infamous example for the existence of hard manual labour under miserable conditions along the supply chain of consumer electronics. In this paper I therefore use the example of Apple for highlighting that an adequate conceptualization of digital labour must not ignore its physical and manual aspects.

In the first section I give a brief overview of the developments that led to the rise of China as the "workshop of the world". In section 2 I contrast Apple's business success with allegations from corporate watchdogs regarding bad working conditions in the company's supply chain. In order to examine these allegations in greater detail I then introduce a systematic model of working conditions (section 3) and apply it to Apple's contract manufacturers in China (section 4). Finally, I discuss Apple's response to labour rights violations (section 5) and conclude with some reflections on solidarity along the global value chain (section 6).

\section{The Rise of China as "Workshop of the World"}

The rise of neoliberal globalization and international value chains is generally considered as a reaction to the crisis of Fordist capitalism in the 1970s (Fröbel, Heinrichs and Kreye 1981; Smith 2012, 40; Harvey 2005, Munck 2002, 45). Part of the restructuring of capitalism was the gradual relocation of large parts of production activities from the industrialized core of the world economy to the former periphery. In this context Fröbel, Heinrichs and Kreye coined the concept of the "new international division of labour" (NIDL). They argue that: "The development of the world economy has increasingly created conditions (forcing the development of the new international division of labour) in which the survival of more and more companies can only be assured through the relocation of production to new industrial sites, where labour-power is cheap to buy, abundant and well-disciplined; in short, through the transnational reorganization of production" (Fröbel, Heinrichs and Kreye 1981,15). As a consequence, commodity production became "increasingly subdivided into fragments which can be assigned to whichever part of the world can provide the most profitable combination of capital and labour" (Fröbel, Heinrichs and Kreye 1981, 15). The result was the emergence of global value chains and production networks in various industries including the electronics sector.

This development had a substantial impact on labour relations and working conditions around the world. As the global labour force expanded (Munck 2002, 109) the protection of labour rights was weakened. McGuigan argues that neoliberal restructurings and the rise of post-Fordism led to "an attack on organized labour in older industrialised capitalist states and devolution of much manufacturing to much cheaper labour markets and poor working conditions of newly industrialising countries" (McGuigan 2005, 230).

The rise of China as the "workshop of the world" needs to be seen in the context of these developments. Hung stresses that "China's labour-intensive takeoff coincided with the onset 
of an unprecedented expansion of global free trade since the 1980s" (Hung 2009, 10). The integration of China into global capitalist production networks was made possible by a number of policy reforms pursued by the Chinese state. David Harvey highlights that the Chinese economic reform programme initiated in the late 1970s coincided with the rise of neoliberalism in the US and the UK (Harvey 2006, 34). This reform program included the encouragement of competition between state owned companies, the introduction of market pricing as well as a gradual turn towards foreign direct investment (Harvey 2006, 39). The first Special Economic Zones (SEZ) in China were established in 1980 (Yeung et al. 2009, 223). The first four SEZ were located in the coastal areas of south-east China: Shantou, Shenzhen and Zhuhai in Guangdong province and Xiamen in Fujian Province (Yeung et al. 2009, 224). By 2002, David Harvey argues, foreign direct investment accounted for more than 40 percent of China's GDP (Harvey 2006, 39).

Hong highlights that China was particularly interested in entering the market for ICT production. In order to boost exports, tax refunds for the export of ICT commodities were set in place In the 1990s (Hong 2011, 37). In 2005 import tariffs for semiconductor, computer and telecommunication products were removed (Hong 2011, 37). These policies proved effective: Hong argues that "In the global market China has emerged as leading ICT manufacturing powerhouse: In 2006, China became the world's second largest ICT manufacturer, and ICT products manufactured in China accounted for over 15 percent of the international trade of ICT products" (Hong 2011, 2).

The fact that attracting foreign direct investment was made possible by granting tax exemptions means that foreign companies could make use of Chinese land area and exploit Chinese labour, while paying only little back to the Chinese public through taxes. Hong shows that by 200540.4 percent of ICT companies in China were foreign enterprises, which controlled 71.1 percent of all profits from the industry, but due to tax benefits these foreign invested ICT enterprises only made up 42.3 percent of the total tax contribution of the sector (Hong 2011, 38).

An effect of the shift towards pro-market policies and the privatization of state enterprises was the massive commodification of labour (Su 2011, 346). The newly established market for labour power replaced the previous system in which workers were guaranteed employment as well as social welfare including medical care, education opportunities, pensions and housing (Friedman and Lee 2010, 509). Zhao and Duffy point out that the adoption of a policy towards foreign direct investment in the ICT sector and the privatization of industries also meant a weakening of the power of the Chinese working class. Older industrial workers were replaced by young, often female migrant workers (Zhao and Duffy 2008, 230).

Low wages and cheap production costs made China attractive for companies in search for outsourcing opportunities. Hung argues that the prolonged stagnation of wages resulted from Chinese government policies that neglected and exploited the rural agricultural sector in order to spur urban industrial growth (Hung 2009 13f). This situation forced young people to leave the countryside in order to find work in the city, creating a "limitless supply of labour" (Hung 2009, 14) while reinforcing "a rural social crisis" (Hung 2009, 14). Among the companies that are taking advantage of the cheap labour supply in China is the computer giant Apple.

\section{Apple: Clean Image versus Dirty Reality}

Steve Wozniak, Steve Jobs and Ronald Wayne founded Apple in 1976 (Linzmayer 2004, 6 ). However, it was not until the mid 2000s that Apple joined the elite of the most profitable companies in the world. In 2005 Apple's profits for the first time exceeded 1 billion USD and during the following years continued to increase rapidly until they reached 41.7 billion USD in 2012 (Apple SEC-Filings. 10-k form $2012^{2}$ ), which made Apple the second most profitable 
company in the world ${ }^{1}$. Between 2000 and 2012 Apple's profits on average grew $39.2 \%$ each year $^{2}$ (Apple SEC-Filings, 10-k form) (see figure 1).

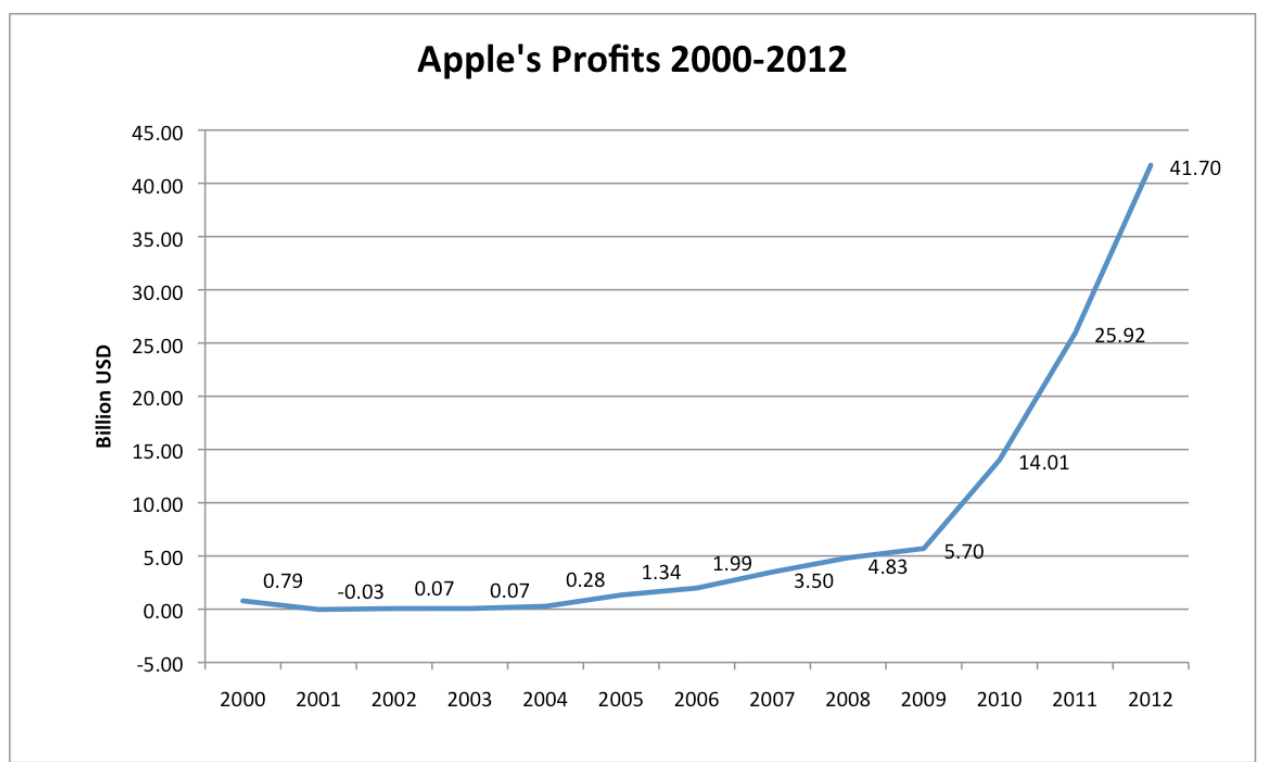

Figure 1: Apple's Profits from 2000 to 2012 (Apple SEC-filings, 10-k forms 2010-2012).

In 2012 Apple's total net sales amounted to 156.51 billion USD. The largest share of it was derived from hardware, whereby the iPhone was Apple's most successful product (see figure 2).

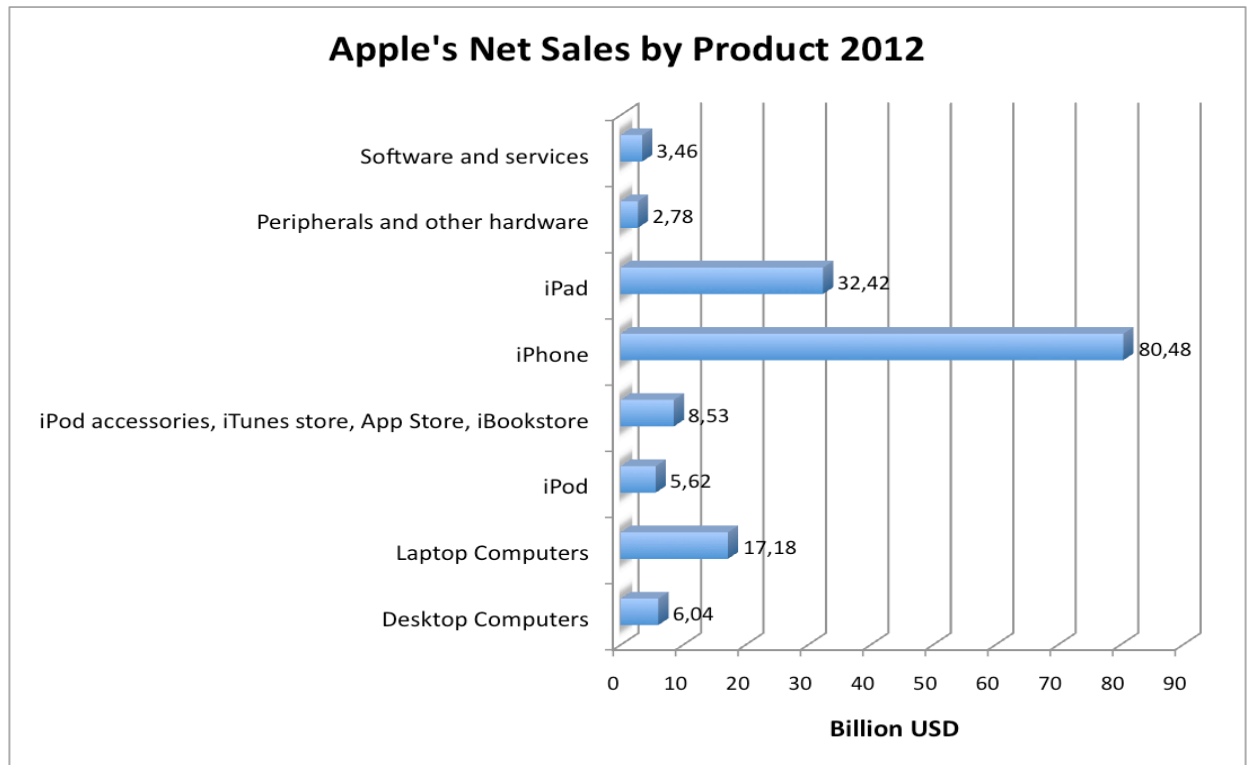

Figure 2: Apple's Net Sales by Product 2012 (Apple SEC-filings, 10-k form 2012, 30).

In addition to its economic success Apple is also successful in building its reputation. Fortune Magazine, for six years in a row (2008-2013), has ranked Apple the most admired company in the world ${ }^{3}$. According to a survey among 47,000 people from 15 countries that was conducted by the consultancy firm Reputation Institute, Apple is the company with the $5^{\text {th }}$ best Corporate Social Responsibility (CSR) reputation worldwide (Reputation Institute 2012, 19).

\footnotetext{
${ }^{1}$ Forbes Magazine. The World's Biggest Public Companies. Retrieved from http://www.forbes.com/global2000/\#page:1 sort:4 direction:desc search: filter:All\%20industries filter:All\%20cou ntries filter:All\%20states on April 24, 2013.

${ }^{2}$ Compound Annual Growth Rate CAGR

${ }^{3}$ Fortune. 2013. World's Most Admired Companies. Retrieved from http://money.cnn.com/magazines/fortune/most-admired/ on April 24, 2013.
} 
This image does not correspond to the company's actual business practices. The production of Apple's hardware products, on which its economic success is built (see figure 1), is largely outsourced to contract manufacturers in China. In May and June 2010 many major Western media reported about a series of suicides at factory campuses in China. The factories, at which 17 young workers jumped to death between 2007 and May $2010^{4}$ belong to the Taiwan-based company Hon Hai Precision Industry Co. Ltd, better known as Foxconn, which is a major supplier for computer giants such as Apple, Hewlett-Packard and Nokia (Finnwatch, SACOM and SOMO 2011, 8).

Hon Hai Precision is a profitable company itself. According to Forbes Magazine it is the $113^{\text {th }}$ biggest company in the world. In 2012 its profits amounted to 10.7 billion USD ${ }^{5}$. Nevertheless the company strongly depends on orders from consumer brands such as Apple. Finnwatch, SACOM and SOMO describe this situation as follows: "These companies often drive down the price they pay their suppliers, which then makes the suppliers less or no longer profitable. To get back in the game, suppliers reduce costs, often at the cost of workers, violating labour laws in the process" (Finnwatch, SACOM and SOMO 2009, 44). Competition between contract manufacturers such as Foxconn is also high, which is why profit rates can often only be achieved by keeping cost low (SOMO 2005a, 41). Although some Foxconn factories are exclusively producing for Apple, such as for example three plants in Zhengzhou, Henan (SACOM 2012, 3), Foxconn is not the only company that is manufacturing Apple products. Other Apple suppliers include Pegatron Corporation, Primax Electronics, Quanta Computers, Wintek or Foxlink ${ }^{6}$. Working conditions are similar throughout these factories (SACOM 2010, 2012, 2013). SACOM argues that "illegal long working hours, low wages and poor occupational health and safety are rooted in the unethical purchasing practices of Apple" (SACOM 2012, 1).

The losers in this corporate race for profit are the workers. When young Foxconn workers decided to end their lives by jumping from their employer's factory buildings, Western media for some weeks were looking behind the surface of bright and shiny computer products. For example, The New York Times published a story about the String of Suicides Continues at Electronics Supplier in China'; the BBC reported on Foxconn Suicides: 'Workers Feel Quite Lonely, ${ }^{8}$, Time Magazine published an article entitled Chinese Factory Under Scrutiny As Suicides Mount ${ }^{9}$; The Guardian headlined Latest Foxconn Suicide Raises Concern Over Factory Life in China ${ }^{10}$, and CNN reported Inside China Factory Hit By Suicides ${ }^{11}$.

However, these suicides are only the tip of the iceberg. For several years NGOs have stressed that computers, $\mathrm{mp} 3$ players, game consoles, etc are often produced under miserable working conditions (ICO, Finnwatch and ECA 2005; SOMO 2005b, SOMO 2007a). Far away from shopping centres and department stores, workers in factories in Asia or Latin America produce consumer electronics devices during 10 to 12 hour shifts, a minimum of 6 days a week for at best a minimum wage. Apple's suppliers are no exception. In the next

\footnotetext{
${ }^{4}$ Wired Magazine. 2011. 1 Million Workers. 90 Million iPhones. 17 Suicides. Who's to blame? By Joel Johnson on Februar 28, 2011. Retrieved from http://www.wired.com/magazine/2011/02/ff joelinchina/all/1 on October 23, 2011.

${ }^{5}$ Forbes Magazine. The World's Biggest Public Companies. Retrieved from http://www.forbes.com/global2000/list/\#page:1 sort:0 direction:asc search: filter:Electronics filter:All\%20countri es filter:All\%20states on May 1, 2013.

${ }^{6}$ Apple. List of Suppliers. Retrieved from http://www.apple.com/supplierresponsibility/our-suppliers.html on May 1, 2013.

The New York Times. 2010. String of Suicides Continues at Electronics Supplier in China. By David Barboza on May 25, 2010. Retrieved from http://www.nytimes.com/2010/05/26/technology/26suicide.html on October 24, 2011.

${ }^{8}$ BBC. 2010. Foxconn Suicides: 'Workers Feel Quite Lonely. On May 28, 2010. Retrieved from http://www.bbc.co.uk/news/10182824 on October 24, 2011.

${ }^{9}$ Time Magazine. 2010. Chinese Factory Under Scrutiny As Suicides Mount. On May 26, 2010. Retrieved from http://www.time.com/time/world/article/0,8599,1991620,00.html on October 24, 2011.

${ }_{10}$ The Guardian. 2010. Latest Foxconn Suicide Raises Concern Over Factory Life in China. By Tania Branigan on May 17, 2010. Retrieved from http://www.guardian.co.uk/world/2010/may/17/foxconn-suicide-chinafactory-life on October 24, 2011.

${ }^{11} \mathrm{CNN}$. 2010. Inside China Factory Hit By Suicides. By John Vause on June 1, 2010. Retrieved from http://articles.cnn.com/2010-06-01/world/china.foxconn.inside.factory 1 foxconn-suicides-china-laborbulletin? s=PM:WORLD on October 24, 2011.
} 
sections I develop a systematic account of working conditions (section 3), which I will subsequently apply to the situation in the workshops of Apple's contract manufactures in China (section 4).

\section{A Systematic Model of Working Conditions}

A suitable starting point for a systematic model of different dimensions of working conditions is the circuit of capital accumulation as it has been described by Karl Marx (1867/1990, $248-253 ; 1885 / 1992,109)$. According to Marx, capital accumulation in a first stage requires the investment of capital in order to buy what is necessary for producing commodities, the productive forces: labour time of workers ( $L$ or variable capital) on the one hand, and working equipment like machines and raw materials (MoP or constant capital) on the other hand (Marx 1885/1992, 110). Thus, money (M) is used in order to buy labour power as well as machines and resources as commodities $(C)$ that then in a second stage enter the labour process and produce (P) a new commodity (C') (Marx 1885/1992, 118). This new commodity (C') contains more value than the sum of its parts, i.e. surplus value. This surplus value needs to be realized and turned into more money (M') by selling the commodity in the market (Marx 1885/1992, 125). The circuit of capital accumulation can thus be described with the following formula: $M \rightarrow C \ldots P$... C' $\rightarrow M^{\prime}$ (Marx 1885/1992, 110)

According to Marx, surplus value can only be generated due to the specific qualities of labour-power as a commodity. Marx argued that labour power is the only commodity "whose use-value possesses the peculiar property of being a source of value, whose actual consumption is therefore itself an objectification of labour, hence a creation of value" (Marx 1867/1990, 270).

Labour is thus essential to the process of capital accumulation. The model I constructed thus takes this process as its point of departure for identifying different dimensions that shape working conditions (see figure 2). The purpose of this model is to provide comprehensive guidelines that can be applied for systematically studying working conditions in different sectors.

\section{THE STATE: Regulatory Frameworks}

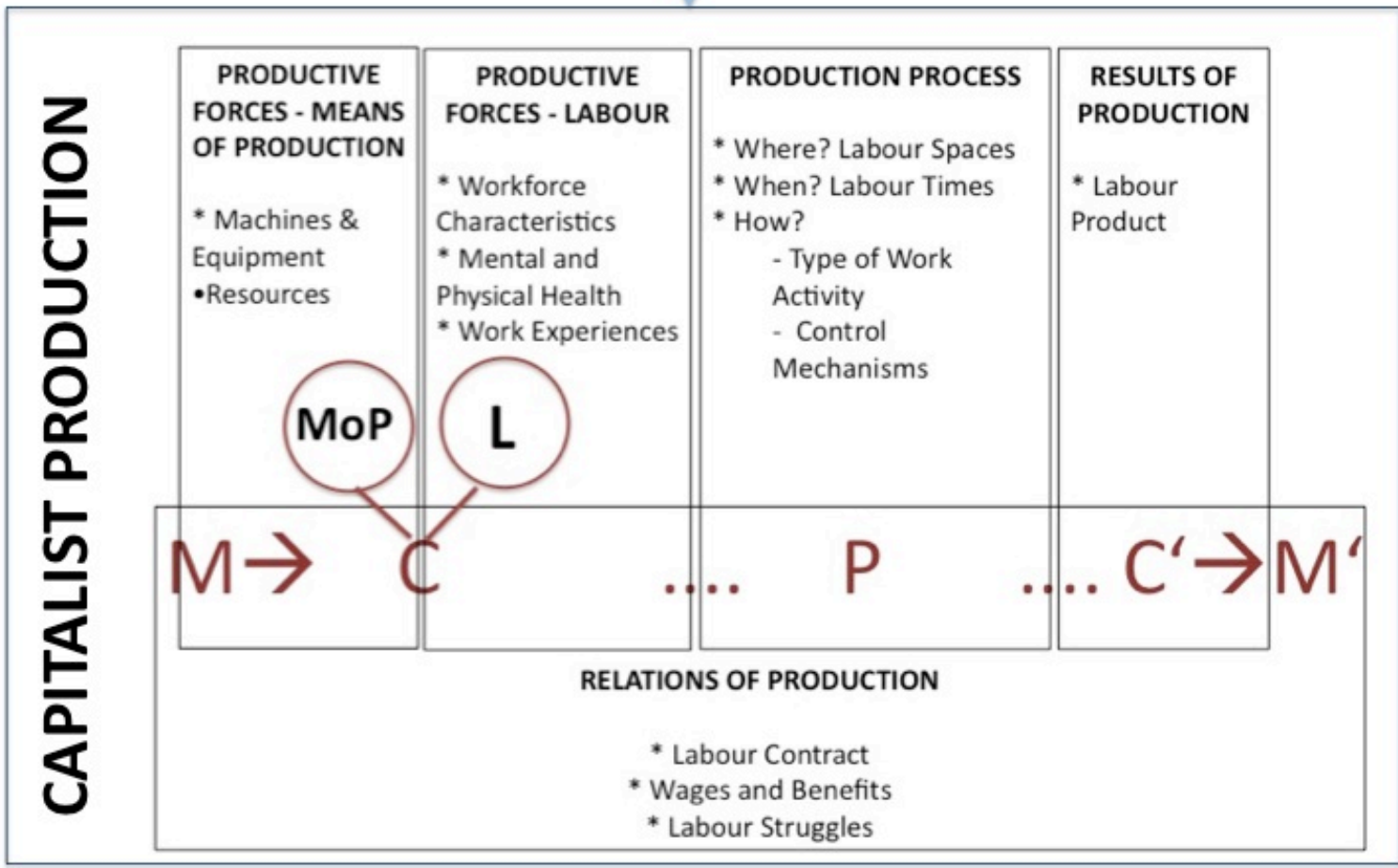

Figure 3: Dimensions of working conditions 
The model pictured in figure 3 identifies five areas that shape working conditions throughout the capital accumulation process: means of production, labour, relations of production, the production process and the outcome of production. Furthermore this model includes the state's impact on working conditions through labour legislation:

- Productive Forces - Means of Production: Means of production include machines and equipment on the one hand and resources that are needed for production on the other hand. The question whether workers operate big machines, work at the assembly line, use mobile devices such as laptops, handle potentially hazardous substances, use high-tech equipment, traditional tools or no technology at all etc. shapes the experience of work and has a strong impact on work processes and working conditions.

- Productive Forces - Labour: The subjects of the labour process are workers themselves. One dimension that impacts work in a certain sector is the question how the workforce is composed in terms of gender, ethnic background, age, education levels etc. Another question concerns worker health and safety and how it is affected by the means of production, the relations of production, the labour process and labour law. Apart from outside impacts on the worker, an important factor is how workers themselves experience their working conditions.

- Relations of Production: Within capitalist relations of production, capitalists buy labour power as a commodity. Thereby a relation between capital and labour is established. The purchase of labour power is expressed through wages. Wages are the primary means of subsistence for workers and the reason why they enter a wage labour relation. The level of wages thus is a central element of working conditions. Labour contracts specify the conditions under which capital and labour enter this relation, including working hours, wages, work roles and responsibilities etc. The content of this contract is subject to negotiations and often struggles between capital and labour. The relation between capital and labour is thus established through a wage relation and formally enacted by a labour contract that is subject to negotiations and struggles. These three dimensions of the relation between capital and labour set the framework for the capitalist labour process.

- Production process: Assessing working conditions furthermore requires looking at the specifics of the actual production process. A first factor in this context is its spatial location. Whether it is attached to a certain place or is location independent, whether it takes place in a factory, an office building, or outdoors etc. are important questions. A second factor relates to the temporal dimension of work. Relevant questions concern the amount of regular working hours and overtime, work rhythms, the flexibility or rigidness of working hours, the relation between work time and free time etc. Finally working conditions are essentially shaped by how the production process is executed. This includes on the one hand the question which types of work activity are performed. The activities can range from intellectual work, to physical work, to service work, from skilled to unskilled work, from creative work to monotonous and standardized work tasks, etc. On the other hand another aspect of the production process is how it is controlled and managed. Different management styles can range from strict control of worker behaviour and the labour process to high degrees of autonomy, self-management or participatory management etc. Space, time, activity and control are essential qualities of the production process and therefore need to be considered when studying working conditions.

- Product: Throughout the production process workers put their time, effort and energy into producing a certain product. This actual outcome of production and how it relates back to the worker thus needs to be considered for understanding work in a certain sector.

- The state: Finally the state has an impact on working conditions through enacting labour laws that regulate minimum wages, maximum working hours, social security, safety standards etc.

Table 1 summarizes the dimensions of working conditions that I described above. 


\begin{tabular}{|c|c|c|}
\hline \multirow[t]{2}{*}{$\begin{array}{l}\text { Productive forces - Means of } \\
\text { production }\end{array}$} & Machines and equipment & $\begin{array}{l}\text { Which technology is being } \\
\text { used during the production } \\
\text { process? }\end{array}$ \\
\hline & Resources & $\begin{array}{l}\text { What resources are used } \\
\text { during the production pro- } \\
\text { cess? }\end{array}$ \\
\hline \multirow[t]{3}{*}{ Productive forces - Labour } & Workforce characteristics & $\begin{array}{l}\text { What are important charac- } \\
\text { teristics of the workforce for } \\
\text { example in terms of age, } \\
\text { gender, ethnic background } \\
\text { etc? }\end{array}$ \\
\hline & Mental and physical health & $\begin{array}{l}\text { How do the employed means } \\
\text { of production and the labour } \\
\text { process impact mental and } \\
\text { physical health of workers? }\end{array}$ \\
\hline & Work experiences & $\begin{array}{l}\text { How do workers experience } \\
\text { their working conditions? }\end{array}$ \\
\hline \multirow[t]{3}{*}{ Relations of production } & Labour contracts & $\begin{array}{l}\text { Which type of contracts do } \\
\text { workers receive, what do } \\
\text { they regulate? }\end{array}$ \\
\hline & Wages and benefits & $\begin{array}{l}\text { How high/low are wage lev- } \\
\text { els and what are other ma- } \\
\text { terial benefits for workers? }\end{array}$ \\
\hline & Labour struggles & $\begin{array}{l}\text { How do workers organize } \\
\text { and engage in negotiations } \\
\text { with capital and what is the } \\
\text { role of worker protests? }\end{array}$ \\
\hline \multirow[t]{4}{*}{ Production process } & Labour spaces & $\begin{array}{l}\text { Where does the production } \\
\text { process take place? }\end{array}$ \\
\hline & Labour times & $\begin{array}{l}\text { How many working hours are } \\
\text { common within a certain } \\
\text { sector, how are they en- } \\
\text { forced and how is the rela- } \\
\text { tionship between work and } \\
\text { free time? }\end{array}$ \\
\hline & Work activity & $\begin{array}{l}\text { Which type of mental and/or } \\
\text { physical activity are workers } \\
\text { performing? }\end{array}$ \\
\hline & Control mechanism & $\begin{array}{l}\text { Which type of mechanisms } \\
\text { are in place that control the } \\
\text { behaviour of workers? }\end{array}$ \\
\hline Results of production & Labour product & $\begin{array}{l}\text { Which kinds of products or } \\
\text { services are being pro- } \\
\text { duced? }\end{array}$ \\
\hline The state & Labour law & $\begin{array}{l}\text { Which regulations regarding } \\
\text { minimum wages, maximum } \\
\text { working hours, safety, social } \\
\text { security etc are in place and } \\
\text { how are they enforced? }\end{array}$ \\
\hline
\end{tabular}

Table 1: Dimensions of working conditions

Based on research that has been conducted by corporate watchdogs I will now take a closer look at all of the described dimensions in Apple's manufacturing factories in China. 


\section{Working Conditions at Apple's Contract Manufacturers in China}

Corporate watchdogs such as Students and Scholars Against Corporate Misbehaviour (SACOM), China Labour Watch and the organisations involved in the European project makelTfair have collected comprehensive data about working conditions in Apple's supply chain. SACOM is a Hong-Kong based NGO that was founded in 2005. It brings together concerned labour rights activists, students, scholars and consumers in order to monitor working conditions throughout China and elsewhere ${ }^{12}$. SACOM's research is largely based on undercover investigations and anonymous interviews with workers, conducted outside of factory campuses. Its research results are documented in reports such as iSlave behind the iPhone (2011b) or New iPhone, Old Abuses (2012) that are made available online. China Labour Watch (CLW) is another independent NGO that was founded in 2000. Since then it has collaborated with workers, unions, labour activists and the media in order to monitor working conditions in different industries in China. CLW's Shenzhen office works directly with local workers and factories, while CLW's New York based office produces investigation report and makes them available to an international audience ${ }^{13}$.

The project makelTfair ${ }^{14}$, funded by the European Union (2006-2012), focuses on working conditions and environmental impacts throughout the live-cycles consumer electronics such as computers, mobile phones, photo cameras or $\mathrm{mp} 3$ players. The research that was conducted within the project is based on anonymous interviews with workers outside factory buildings and sometimes also includes interviews with management officials. Workers tend to be hesitant to answer questions about their working conditions as they depend on their jobs and are afraid of negative consequences, especially if the investigators are foreigners. Therefore the European project partners such Swedwatch, Germanwatch, SOMO, Finnwatch or Danwatch co-operate with local NGOs and researchers who approach and interview workers without the knowledge of factory managers. MakelTfair informs the electronics brand companies such as Apple, Dell or HP of its research results and invites them to comment on the findings. Based on its research makelTfair aims at raising awareness among consumers, activists and policy makers about the work and life reality of workers in the manufacturing of consumer electronics and to pressure electronics companies to improve working conditions in their supply chains.

I will in the following use data provided by these corporate watchdogs in order to shed light on the work reality of those who are manufacturing Apple's products in China.

\subsection{Productive Forces - Means of Production}

According to Marx, means of production consist of tools and instruments on the one hand and raw materials on the other hand (Marx 1867/1990, 284f). The fact that in capitalism means of production are privately owned lays the foundation for exploitation and the domination of man by man: "modern bourgeois property is the final and most complete expression of the system of producing and appropriating products, that is based on class antagonism, on the exploitation of the many by the few" (Marx and Engels 1848/1991, 46). For the majority of people private ownership of means of production in fact means non-ownership. Being deprived from the necessary capital to buy means of production that are needed to engage in a production process, workers have to sell their labour power in order to earn their means of subsistence. Private ownership of machines and equipment as well as resources is thus the starting point of the capitalist labour process. I will now consider which instruments (see section 4.1.1) and resources (see section 4.1.2) are needed for producing Apple's products.

\footnotetext{
12 SACOM. About Us. Retrieved from http://sacom.hk/about-us on July 22, 2013.

${ }^{13}$ China Labour Watch. Who We Are. Retrieved from http://www.chinalaborwatch.org/aboutus.html July 22 , 2013.

${ }^{14}$ MakelTfair: http://makeitfair.org/en?set language=en
} 


\subsubsection{Machines and Equipment}

Compared to other manufacturing sectors such as apparel or toys, electronics manufacturing is relatively capital intensive and requires high-tech equipment (Plank and Staritz 2013, 4; Lüthje 2006, 22). This is even more the case as computer products are becoming more sophisticated smaller in size and lower in weight (WTEC 1997, 16). However the consultancy firm McKinsey \& Company classifies the final assembly of high-tech products as labourintensive (McKinsey \& Company 2012, 64). One reason for this is that the fragmentation of the production process allows to separate "labour-intensive and more capital- and knowledge- intensive parts" so that "there is a considerable amount of low-value and thus low-skill and low-wage activity, which is often combined with advanced production technologies in this 'high-tech' sector" (Plank and Staritz 2013, 9). Electronics manufacturing is thus characterized by both high-tech equipment and high demand for labour.

Electronics manufacturing is among those industries that account for the most robot purchases. According to McKinsey and Company "in 2010, automotive and electronics manufacturing each accounted for more than 30,000 robot units sold globally, while industries such as food and beverage, rubber and plastics, and metal products each bought only 4,000 to 6,000 new robots" (McKinsey \& Company 2012, 88).

A technology that Apple's contract manufacturers employ for the automated part of assembly is Surface Mount Technology (SMT) (WTEC 1997, 16; Lüthje 2012). SMT uses programming to automatically solder electronics components such as chips or connectors onto circuit boards ${ }^{15}$. Boy Lüthje argues that as labour costs in China are low not the entire potential of automation is realized, thus "the degree of automation in most factories in China and Asia is lower than it would be in Europe or the United States" (Lüthje 2012). This means that labour is sometimes cheaper than high-tech equipment. It also means that making use of the full range of available automation technology could eliminate parts of the repetitive and standardized work activities that are now part of electronics production.

\subsubsection{Resources}

Among the resources needed for the production of consumer electronics such as Apple's Mac's, iPads, iPhones and iPods are minerals such as tin, beryllium, gallium, platinum tantalum, indium, neodymium, tungsten, palladium, yttrium, gold, and cobalt (SOMO 2007b, 1012, Friends of the Earth 2012, 7; Mvoplatform and GoodElectronics 2009, 25). Often these minerals are sourced in conflict areas (SOMO 2007b, 13). The mining activities usually take place under extremely poor health and safety conditions, are extremely low paid, require the resettlement of local villages, threaten the environment and the livelihood of local communities (SOMO 2007b; 2011; Swedwatch 2007; Finnwatch 2007).

Cobalt for example is mainly extracted in the so-called copperbelt in Zambia and the Democratic Republic of Congo (DRC) (Swedwatch 2007, 7). It is needed for the production of rechargeable batteries for laptops, mobile phones etc as well as for speakers, headphones and the coatings of hard drives (Swedwatch 2007, 12). Swedwatch in an investigation of mining activities in the Katanga province in DRC found that worker are risking their lives for an income of about 2-4 USD per day (Swedwatch 2007, 29,33). Many of the miners are children: An estimated number of 50,000 children between the age of 7 and 18 are working in the mines of Katanga and thus form a large part of the total workforce of 10,000-14,000 miners (Swedwatch 2007, 7).

The DRC is rich on mineral resources but has been shaped by poverty as well as colonial violence, civil war and armed conflict. A report by Free the Slaves shows that in DRC mines are often controlled by armed rebel groups that force local people into slavery (Free the Slaves 2011, 11). Many women and girls, who are often not allowed to work in the mines, are forced into sexual exploitation (Free the Slaves 2011, 17f).

It is difficult to determine where exactly and under which conditions the minerals contained in a product of a certain electronics brand were soured. However sometimes watchdogs suc-

\footnotetext{
${ }^{15}$ Surface Mount Technology Association. Glossary of Acronyms Relevant to Electronics Manufacturing. Retrieved from http://www.smta.org/files/acronym glossary.pdf on May 18, 2013.
} 
cessfully trace the supply chain of a brand back to the point of mineral extraction. In 2012 Friends of the Earth published a report that traces the tin used in Apple's iPhones back to mines in Bangka, an island in Indonesia. The report reveals that Foxconn and Samsung, which are Apple's direct suppliers, buy their tin from the middle companies Shenmao, Chernan and PT Timah, which obtain their tin from Indonesia. $90 \%$ of Indonesian tin is mined at Bangka island (Friends of the Earth 2012, 21). The report shows how tin mining destroyed forests and farmlands, killed coral, seagrass and mangroves and led fish to disappear, contaminated drinking water (Friends of the Earth 2012, 13). The destruction of the ecosystem deprives local farmers and fishermen of their livelihood, forcing them to become tin miners themselves (Friends of the Earth 2012, 15f). Tin mining at Bangka island is dangerous and security standards are low. Friends of the Earth reports that that in 2011 on average one miner per week was killed in an accident (Friends of the Earth 2012, 9).

Conflict minerals are used for producing electronics parts such as researchable batteries (cobalt), magnets (cobalt), speakers (cobalt), power amplifiers (gallium), camera flashes (gallium), high efficiency transistors (Indium), flat screens (indium, platinum), lead frames (palladium), plating connectors (palladium), chip resistors (ruthenium), capacitors (neodymium, lanthanum, tantalum) or circuit boards (tin) (Finnwatch 2007, 9f).

Long before minerals enter the final assembly process of consumer electronics, they have passed through a process framed by destruction and exploitation. It is important to recognize this history of the components that are assembled in Apple's manufacturing factories. Threats to workers and the environment connected to these minerals however continue: Due to the toxic qualities of many minerals they can potentially harm workers in electronics manufacturing. Furthermore the fact that toxic minerals are contained in electronics products can cause problems at the point of disposal. Toxic electronic waste often ends up in waste dumps in the global South where it contaminates the environment and threatens the health of waste worker (Danwatch 2011).

\subsection{Productive Forces - Labour}

Focussing on the subjective side of the labour process, at workers themselves, shows that work on Apple's manufacturing sites is often performed by young female migrant workers (see section 4.2.1), who are exposed to serious health hazards (see section 4.2.2) and experience their daily work life as alienating and exhausting (see section 4.2.3).

\subsubsection{Workforce Characteristics}

The majority of production workers in China are young female migrant workers (Bread for All 2007, 6; FinnWatch, SACOM and SOMO 2009, 17). Estimates show that in the Chinese Guangdong province, for example, migrant workers make up 65 percent of the workforce in the manufacturing sector (Finnwatch, SACOM and SOMO 2009, 17).

Migrant workers are a particularly vulnerable group of workers. Far away from their hometown they lack social contacts and are therefore prone to isolation. Migrant workers also receive less social benefits. According to the FLA investigation migrant workers at Shenzhen - which constitute $99 \%$ of the total workforce - are not covered by unemployment and maternity insurance systems because they do not have a Shenzhen residence card (FLA 2012, 9). Even if migrant workers have unemployment insurance they often cannot claim benefits in their hometown due to lacking transfer agreements between provinces (FLA 2012 , 9). Chinese laws prevent migrant workers to officially become urban citizens who are entitled to education and medical care in the city. They remain always dependent on their social networks in their hometowns especially in times of unemployment, illness or pregnancy. This situation keeps many workers trapped as permanent migrants (Friedman and Lee 2010, 516).

Many workers in the electronics industry are young women, who leave their families on the countryside to find work in an industrial area and provide some financial assistance for their relatives. Often factories prefer to hire female workers because they are considered to be good at performing detail-oriented work and to be more obedient and less likely to engage in protests (Swedwatch, SACOM and SOMO 2008, 11). 
Workers often have no other choice than to find employment in a factory in order to be able to earn enough money to support themselves and their families. This dependency increases the power of companies over workers. The lack of alternatives makes it likely that workers feel forced to accept bad working conditions.

\subsubsection{Mental and Physical Health}

Threats to health and safety in electronics factories result from the usage of hazardous substances, insufficient information of workers about the substances they are using, a lack of protection equipment and unsafe work routines. During the last couple of years a number of serious incidents occurred at Apple's supplier factories.

For example between July 2009 and early 2010, 47 workers at United Win, a subsidy of Wintek Corporation that produces Apple products, were hospitalized because of being poisoned with n-hexane (SACOM 2010, 2). If inhaled, n-hexane can cause nerve damage and paralysis of arms and legs. The poisoned workers were using n-hexane for cleaning iPhone touch screens (SACOM 2010, 2). When the first poisoning occurred workers organized a strike. As a result United Win organized health examinations. However, no poisoning was diagnosed during these examinations. The affected workers therefore went to a hospital outside the factory, in which the poisoning was finally diagnosed (SACOM 2010, 2). Similar health hazards were also found at Futaihua Precision Electronics, a Foxconn subsidiary in Zhengzhou, where around 52,500 workers are producing 100,000 iPhones per day. Workers were exposed to chemicals such as $\mathrm{n}$-hexane without adequate protection equipment. Some workers suffered from allergies (SACOM 2011b, 7).

In 2011 SACOM monitored Foxconn's Chengdu factory that produces exclusively for Apple. The investigation revealed an alarming occupational health and safety situation. SACOM found poor ventilation, insufficient protection equipment and noisy workplaces. Workers were using chemicals, without knowing whether they were harmful. At the milling and the polishing department - in which the iPads's aluminium cover is polished until it is untarnished and shiny - workers were constantly breathing in aluminium dust. Several workers were suffering from a skin allergy after working with glue like substances without wearing gloves (SACOM 2011a, 14). Shortly after SACOM's report was published, aluminium dust triggered an explosion at the polishing department at Chengdu that killed 3 workers and left 15 injured (SACOM 2011b, 1; Friends of Nature, IPE, Green Beagle 2011, 36). The Chengdu campus, which consists of eight factory buildings, was built in only 76 days in order to meet growing demand from Apple. Furthermore workers were insufficiently trained and not aware of the dangers connected to aluminium dust (Friends of Nature, IPE, Green Beagle 2011, 37f).

A similar incident occurred at the iPhone polishing department at a Pegatron factory in Shanghai in December 2011. 61 workers were injured (SACOM 2013, 8). SACOM furthermore reports that weak ventilations system at Pegatron's polishing department creates high levels of dust that cover worker's faces and penetrate their masks entering their noses and mouths (SACOM 2013, 8).

Working conditions at electronics manufacturing factories are not only threatening workers' physical health but also creating psychological problems. Social life at Foxconn is deprived. Workers do not have time for any free time activities. Their life consists of working, eating and sleeping. Often they do not even find enough time to sleep. When asked what they would like to do on holiday most interviewees said that they would like to sleep (SACOM 2011a, 12). Workers lack social contacts. SACOM's research shows that workers were not allowed to talk during work. They live in rooms with workers from different shifts, which they therefore hardly ever meet (SACOM 2011a, 12f, FinnWatch, SACOM and SOMO 2011, 30).

Work and life at factory campuses have severe impacts on the bodies and minds of workers. The example of Apple's supplier factories in China illustrates that for many workers selling their labour power also means selling their mental and physical health.

\subsubsection{Work Experiences}

During the past five years corporate watchdogs have interviewed numerous workers at Apple's supplier factories. These interviews reveal that workers experience their work as 
exhausting and alienating. They feel stressed and under pressure in order to achieve production targets (FinnWatch, SACOM and SOMO 2011, 30) as well as exhausted due to extremely long working hours, long hours of standing, and stress during meal breaks (SACOM 2011a, 15).

One worker told SACOM that workers they feel that Apple's demand dictates their entire lives. Workers are torn between the need to increase their salary by working overtime and the need to rest:

"The daily production target is 6,400 pieces. I am worn out every day. I fall asleep immediately after returning to the dormitory. The demand from Apple determines our lives. On one hand, I hope I can have a higher wage. On the other hand, I cannot keep working everyday without a day-off" (Foxconn worker quoted in SACOM 2012, 5f).

Workers furthermore experience their work environment as unsafe and unpleasant. They are worried about their health due to a lack of protection equipment:

"In my department, the working conditions are unbearable. I'm a machine operator, producing the silver frame for the iPhone. We have to put some oil into the machines in the production. I don't know what kind of substance it is and the smell is irritating. The frontline management confided to us that we should not stay in the department for over a year because the oil could cause problems to our lungs. Although the shop floor has air conditioning, it is very hot and the ventilation is poor. For me, the installation of the airconditioners is just a tactic to avoid paying high temperature subsidy to the workers" (Worker quoted in SACOM 2011b, 9).

Furthermore workers describe the way they are controlled and managed as humiliating and exhausting:

"We have to queue up all the time. Queuing up for bus, toilet, card-punching, food, etc. During recess, we don't have a place to sit. We can only sit on the floor. We get up in early morning and can only return to the dorm in late evening. I am really worn out" (Worker quoted in SACOM 2011a, 15).

Workers are aware of the alienating character of their work situation, which expressed by the fact that they are not able to own the products that they are themselves producing every day: One worker told SACOM:

"Though we produce for iPhone, I haven' $t$ got a chance to use iPhone. I believe it is fascinating and has lots of function. However, I don't think I can own one by myself" (Worker quoted in SACOM 2011a, 19).

These descriptions show that workers find themselves in a state of exhaustion and alienation. Karl Marx in 1844 in the Economic and Philosophic Manuscripts described the alienation of worker as his/her labour becoming an external object that "exists outside him, independently, as something alien to him" (Marx 1844/2007, 70). The more life the workers puts into his/her product, the more alienated s/he becomes: "The worker puts his life into the object; but now his life no longer belongs to him but to the object. [...] The greater this product, the less is he himself" (Marx 1844/2007, 70).

Workers in Apple's manufacturing factories have put their labour power into these products while producing them. Many workers left their families, gave up their free time and their health for producing products, which they will never be able to own. The finished products, although containing the workers' energy and labour, suddenly turn out of their reach. Workers are inside Apple's products, but at the same time insurmountably separated from them.

\subsection{Relations of Production}

The relation between capital and labour needs to be understood as a relation of domination. In capitalism the only commodity workers possess is their labour power. In order to make a living they thus have no other choice but to sell it by entering into a wage labour relationship (Marx 1867/1990, 272). Research conducted by corporate watchdogs shows that the relation between capital and labour in Apple's supplier factories in China is largely based on precari- 
ous labour contracts (see section 4.3.1), characterized by low wages (see section 4.3.2) and occasionally contested through labour struggles (see section 4.3.3).

\subsubsection{Labour Contracts}

Labour contracts that offer weak protection for workers are an expression of the unequal power relation between employers and workers. In 2004 the Institute for Contemporary Observation (ICO), FinnWatch and the Finnish Export Credit Agency (ECA) investigated the Shenzhen Foxconn campus. They found that workers could be dismissed anytime. If dismissed, employees had to leave immediately without any financial compensation. If a worker decided to quit and to leave immediately s/he would not receive her/his outstanding wage (ICO, Finnwatch and ECA 2005, 17).

Watchdogs found instances where workers in Apple supplier factories did not receive any contract at all (ICO, Finnwatch and ECA 2005, 17, Swedwatch, SACOM and SOMO 2008, 42; Bread for All and SACOM 2008, 19). Without a signed contract workers are deprived of the possibility of taking legal steps in the case of labour law violations.

The majority of labour contracts in Apple's supplier factories are precarious. Short-term contracts allow supplier companies to remain flexible and to quickly respond to fluctuations of Apple's demand. Another measure Foxconn uses in order to cover sudden increases of labour demand is to recruit workers from labour agencies, or to relocate workers from other cities and provinces to another factory that has a heightened demand for workers (SACOM $2012,8)$. So-called dispatch or agency workers are hired by labour agencies rather than being employed directly by the contract manufacturer. According to SACOM around $80 \%$ of the total workforce of the Apple supplier factories Foxlink in Guangdong, Pegatron in Shanghai and Wintek in Jiangsu are agency workers (SACOM 2013,4). Often social insurance schemes do not cover agency workers (SACOM 2013, 4).

New workers often have a probationary period between three and six months during which their wages are lower than those of permanent workers For example, the wage increases Foxconn implemented after the suicide tragedies were only granted to workers that had been working in the facility for more than six months (Finnwatch, SACOM, SOMO 2011, 28).

Another common practice among Apple's contract manufacturers is the employment of student interns. Especially during peak season students are hired in order to cover the sudden labour demand (SACOM 2012, 6). Students are cheaper to employ since they do not receive regular social security benefits and are not covered by labour law. They however have to work night shifts and overtime like regular workers. Student workers complain that the work they have to perform in Apple supplier factories is unskilled labour that is unrelated to the subject of their studies. Although students officially are not allowed to work more than eight hours per day, they are treated like regular workers and have to work overtime as well as night shifts (SACOM 2011a, 18). They also feel forced to work at these factories, as they are afraid that they will not be able to graduate if they refuse to complete the internship (SACOM 2013,6). Su argues that the internship programs led to the commodification of both student's labour and education (Su 2011, 342). Internship programmes allow factories such as Foxconn to exploit student labour for a profit. In return for sending students to factories technical schools receive equipment and funding (Su 2011, 350).

Finnwatch, SACOM and SOMO found that large numbers of 16- to 18-year old students were employed in Foxconn factories for periods between four and six months (Finnwatch, SACOM and SOMO 2009, 36; Finnwatch, SACOM an SOMO 2011, 5 see also Su 2011, 345). SACOM quotes reports form Chinese media according to which in 2010 100,000 vocational school students from Henan province were sent to work at a Foxconn plant in Shenzhen to complete a 3-month internship (SACOM 2011b, 3). An investigation by the Fair Labour Association (FLA), that Apple had requested, confirmed that Foxconn did not comply with the standards regarding maximum working hours for student interns. Like regular workers, students had to work overtime and nights shifts (FLA 2012, 10).

Short-term precarious contracts and weak protection against dismissal increase factory management's power over workers. It makes workers vulnerable and serves as a means for controlling their behaviour by threat of dismissal. Because workers need to fear loosing their 
jobs they are more likely to agree to higher production targets or increased overtime. Precarious contracts make long-term life planning difficult. Short notice periods leave workers hardly any time to rearrange their lives after a dismissal. Furthermore different types of contracts create divides between workers with fixed contracts, short-term contracts, agency contracts or internship contracts. The fact that different types of contracts confront workers with different kinds of problems makes it more difficult to formulate collective demands.

\subsubsection{Wages and Benefits}

Among the most pressing problems that occur throughout Apple's supplier factories is the low wage level. Already in 2007 the Dutch non-profit research centre SOMO (2007a) interviewed workers at five Apple supplier factories in China, the Philippines and Thailand: Workers in all investigated factories reported that their wages were too low to cover their living expenses. Wages at the Chinese factory of Volex Cable Assembly Co. Ltd. were found to be below the legal minimum (SOMO 2007a, 21). However, even if wages comply with minimum wage regulations they are often hardly enough to cover basic living expenses. In 2008 for example FinnWatch, SACOM and SOMO monitored buildings C03 and C04 of Foxconn's Shenzhen campus, in which 2,800 workers at 40 assembly lines are producing black and white models of the iPhone 8G and 16G (FinnWatch, SACOM and SOMO 2009, 35). Wages corresponded to the legal minimum wage of around 980 yuan, which however is not an adequate living wage (FinnWatch, SACOM and SOMO 2009, 36, 44). A living wage should cover expenses for food, housing, clothes, education, social security and health care for a family, and allow for some savings ${ }^{16}$.

After the suicide tragedies, Foxconn announced significant wage raises ${ }^{17}$. FinnWatch, SACOM and SOMO in 2010 did a follow up study at Apple's production line at Foxconn's Shenzhen campus in order to investigate how the promised wage raises ${ }^{18}$ were implemented. 30 workers were interviewed. The investigation showed that Foxconn in June 2010 increased monthly wages from 900 Yuan to 1,200 Yuan (137 EUR). In October 2010 wages were further raised to 2,000 Yuan (229 EUR), but only for workers who had been working at the factory for more than six months. However, only estimated $50 \%$ of the workforce actually worked longer than 6 months in this factory (FinnWatch, SACOM and SOMO 2011, 28). Furthermore the wage increases only applied to Shenzhen and not to newly established upcountry factories to which Foxconn is increasingly relocating its production (FinnWatch, SACOM and SOMO 2011, 8).

In 2011 SACOM conducted a similar investigation at three other Foxconn campuses in order to evaluate once more how effective the proposed changes really were and whether they improved working and living conditions of employees. SACOM visited Foxconn campuses at Shenzhen, Chengdu and Chongqing and found that Foxconn had increased wages, but at the same time cancelled food and housing subsidies. This means that despite Foxconn's claims there was no actual wage increase (SACOM 2011a, 6). Foxconn was not paying a living wage. Figure 3 shows SACOM's estimations regarding the gap between actual basic wages and living wages in April 2011.

\footnotetext{
${ }^{16}$ The Asia Floor Wage Campaign (2009) suggested a method for calculating the living wage. According to this calculation a living wage needs to cover the costs for food, equivalent of 3000 calories per adult family member multiplied by two, in order to cover also other basic need such as clothing, housing, education, healthcare, and savings. The living wage should provide for a family of two adults and two children. It thus should cover the cost for food worth 3000 calories for three consumption units (two adults and two children) multiplied by two. It is thus calculated as follows: price for food worth 3000 calories $\times 3 \times 2$ (Asia Floor Wage Campaign 2009, 50). A worker should be able to earn a living wage within a working week of a maximum of 48 hours. This calculation of a living wage was developed with specific regard to the garment sector, but is also applicable for other sectors such as electronics manufacturing.

${ }^{17}$ Reuters 2010. Foxconn to Raise Wages Again at China Plant. Retrieved from http://www.reuters.com/article/2010/10/01/us-foxconn-idUSTRE6902GD20101001 on April 28, 2013.

${ }^{18}$ Reuters 2010. Foxconn to Raise Wages Again at China Plant. Retrieved from http://www.reuters.com/article/2010/10/01/us-foxconn-idUSTRE6902GD20101001 on April 28, 2013.
} 


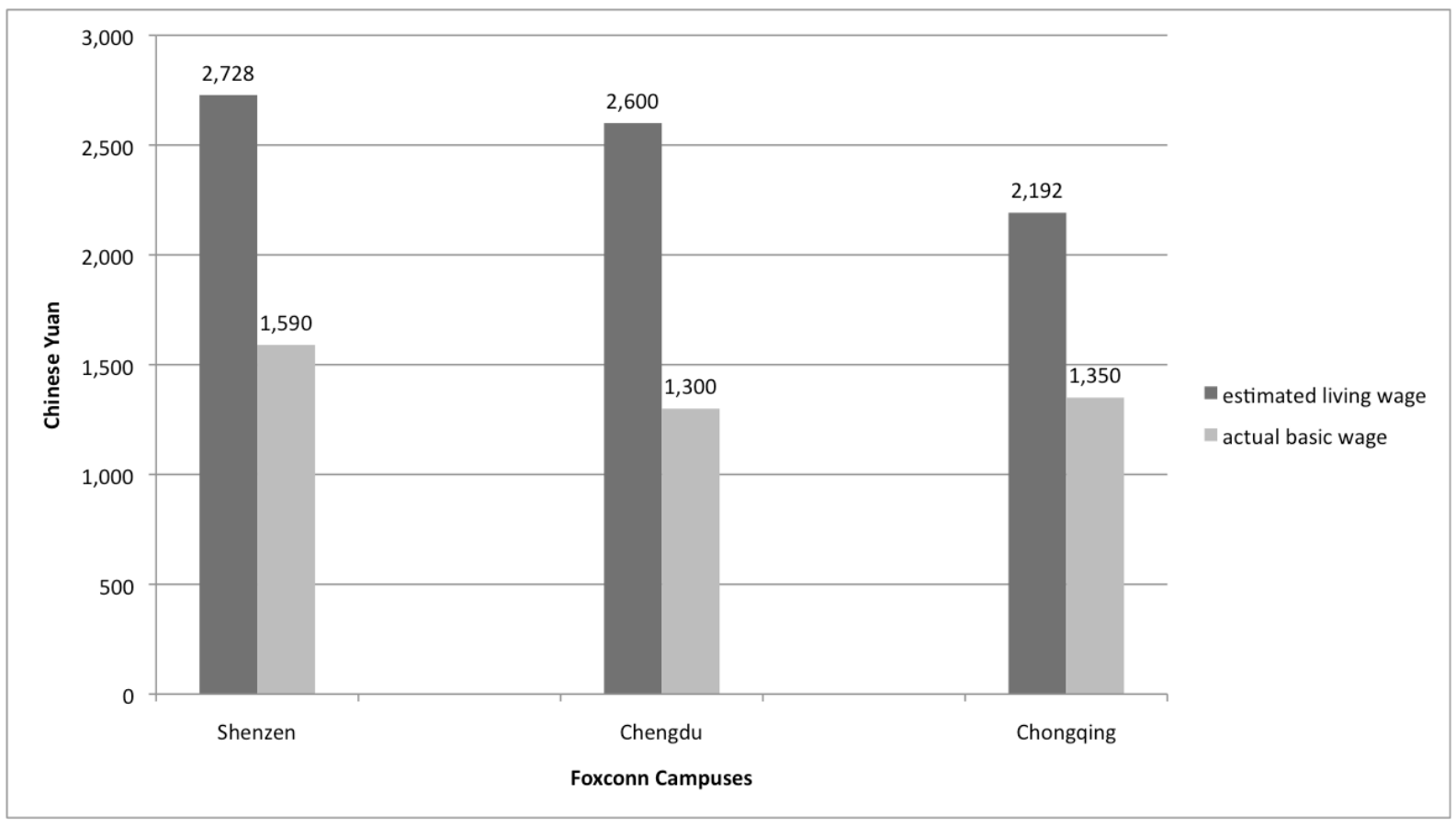

Figure 3: Actual basic wages in comparison to estimated living wages at Foxconn campuses in April 2011 (SACOM 2011a, 6, 9)

SACOM argues that one strategy Foxconn employs to avoid wage increases is to send workers away from cities with higher wage levels, such as Shenzhen, to ones with lower wages levels such as Chengdu (SACOM 2011a, 5f).

The investigation conducted by the Fair Labour Association (FLA) confirms that workers at Apple suppliers perceive their wages as too low. In a survey that assessed the work satisfaction of 35,166 workers at two Foxconn campuses in Shenzhen and one Foxconn campus in Chengdu $64.3 \%$ of all respondents and $72 \%$ of respondents working at Foxconn's Chengdu campus reported that their wages do not cover their basic needs (FLA 2012, 9).

Apple is the second most profitable company in the world. These high profits are made possible at the cost of workers. According to calculations made by Kraemer, Linden and Dedrick in 2010 Apple kept $58.5 \%$ of the sales price of an iPhone, the costs of materials amounted to $21.9 \%$ of the sales prize while only $1.8 \%$ were spent for the labour cost for final assembly in China. For the iPad Chinese labour costs amount to $2 \%$, input materials to $31 \%$ and Apple's profits to $30 \%$ of the sales price (Kraemer, Linden and Dedrick 2011,5). The less Apple has to spend for paying wages the higher are the company's profits. While Apple could certainly afford spending more money for the manufacturing of its products, this would have a negative impact on its profit goals.

Marx stressed that capitalism is based on a contradiction between capital and labour: "Political economy starts from labour as the real soul of production; yet to labour it gives nothing, and to private property everything" (Marx 1844/2007, 81). The example of Apple illustrates this fundamental injustice: Apple's success would be impossible without the work performed in its supplier factories. This work allowed Apple to become the second most profitable company in the world, while it left workers impoverished.

\subsubsection{Labour Struggles}

The low wage level is only one of the reasons why workers engage in strikes and protests. For example on January 15, 2010, 2,000 workers at United Win that produce Apple's iPad organized a strike (SACOM 2010, 1). On November 15, 2011 several thousand workers of 
the Foxconn facility in Foshan were protesting against low wages ${ }^{19}$. In January 2013 over 1,000 workers protested at Foxconn facility in Fengcheng held demonstrations against low wages and bad working conditions ${ }^{20}$.

Such protests are not without risks for factory workers. In 2011 during an investigation at Foxconn's Zhengzhou factory some interviewees told SACOM about workers being dismissed after attempting to strike (SACOM 2011b, 10). In January 2011 the police arrested around 20 workers at another Foxconn facility while protesting against miscalculations of wages (SACOM 2011a, 8).

Labour unions only play a limited role in these protests. The only official trade union in China is the All China Federation of Trade Unions (ACFTU), which is subordinate to the Chinese Communist Party (Friedman and Lee 2010, 521). Friedman and Lee argue that the ACFTU acts like a government agency that represents workers in a top-down process, promotes the introduction of labour laws, provides legal consultation to workers but is opposed to widespread worker mobilization (Friedman and Lee 2010, 521f).

Often workers either do not know what a union can do for them or do not even know that a union exists at their factory (Finnwatch, SACOM, SOMO 2009 \& 2011). Similarly FLA in 2012 found that worker had very little knowledge about the function and activities of worker representatives. Furthermore the FLA found that unions at Foxconn often consist of supervisors or mangers (FLA 2012, 11).

In response to the findings of the FLA Foxconn in February 2013 announced that it will hold democratic union elections ${ }^{21}$. However a study conducted by a corporate watchdog shows that in March and April 2013, 90.2\% of 685 questioned Foxconn workers had not heard about any election plans (The New Generation Migrant Workers Concern Programme $2013,6)$. The results show that more than $50 \%$ of the respondents did not know that union members can democratically elect their representatives and that they can themselves come forward as a candidate. $82.5 \%$ of the workers did not know who the leader of their union group was. $16.9 \%$ of the respondents reported that they are union members. Further $24.6 \%$ said that they think that they are members of a union. These numbers show that actual union enrolment is much lower than $86.3 \%$, the number given by Foxconn officials (The New Generation Migrant Workers Concern Programme 2013, 4f)

Despite these low levels of awareness regarding the existing union the survey results show that workers nevertheless think that unions could potentially help to improve their situation. $45.8 \%$ of the interviewed Foxconn workers think that a union can play a "very important" role in achieving wage increases, while only $3.4 \%$ think that unions are "not important" in this context (The New Generation Migrant Workers Concern Programme 2013, 7). Fostering awareness among workers regarding their rights and strengthening their right to choose union representatives thus seems crucial to support the struggle of workers over their working conditions.

There is the potential that Chinese workers become important agents of labour struggle in the $21^{\text {st }}$ century. In this context Zhao and Duffy highlight: "The fact that tens of thousand of Chinese workers are engaging in daily struggles over hand-to-mouth issues must qualify any sweeping post-Marxist formulations by Western-centric scholars about the disappearance of the working class as historical agents of struggle in the information age" (Zhao and Duffy 2008, 244). In this context Time Magazine in March 2013 reported that "Resentment is reaching a boiling point in China's factory towns. [...] Facing long hours, rising costs, indifferent managers and often late pay, workers are beginning to sound like true proletariat“22. Rather than regarding Chinese workers at Apple's suppliers and elsewhere as mere victims of

\footnotetext{
${ }^{19}$ M.I.C. Gadget. 2010. More Problems With Foxconn; Workers Protest Against Their Wages. Retrieved from http://micgadget.com/9620/more-problems-with-foxconn-workers-protest-against-their-wages/ on October 27 , 2011.

${ }^{20}$ SACOM. 2013. Strike Erupted Over Dire Working Conditions at Foxconn. Retrieved from http://sacom.hk/archives/971 on May 14, 2013.

${ }^{21}$ Financial Times. February 3, 2013. Foxconn plans Chinese Union Vote. Retrieved from http://www.ft.com/cms/s/0/48091254-6c3e-11e2-b774-00144feab49a.html\#axzz2TFz9DeNG on May 14, 2013.

${ }^{22}$ TIME Magazine. Karl Marx's Revenge
} 
capitalist exploitation it is important to recognize that collectively organized they can cause severe disruptions to the global value chain.

On several occasions activists around the world have supported the struggle of Chinese workers. NGOs and labour rights activists have been protesting against Apple tolerating unbearable working conditions in its supplier factories. For example on May 7, 2011 an international day of action against unacceptable treatment of workers was held. MakelTfair, a project of a group of European corporate watchdog organizations, under the slogan "Time to bite into a fair Apple; Call for sustainable IT!" organized protest events throughout Europe ${ }^{23,24}$. SACOM organized a protest street theatre in Hong Kong ${ }^{25}$. Such international solidarity from activists can support worker struggles by raising awareness within Western civil society regarding the work and life reality of Chinese factory workers.

\subsection{Production Process}

In the production process labour power and means of production are employed in order to produce a commodity (Marx 19867/1990, 284). Taking a closer look at the production process in the factories of Apple's contract manufacturers reveals a predominance of unpleasant and unsafe labour spaces (see section 4.4.1), long working hours (see section 4.4.2), standardized and repetitive production steps (see section 4.4.3) and strict and often humiliating control mechanisms (see section 4.4.4).

\subsubsection{Labour Spaces}

Work at Apple's contract manufacturers takes place within the boundaries of the factory. Shopfloors often lack proper ventilation systems, which means that the work environment is hot, dusty and has a strong chemical smell (SCAOM 2011b, 7). The behaviour of workers within their work spaces is strongly controlled: Workers at Foxconn have to pass through security checks with metal detectors when entering or leaving the shopfloor as well as bathrooms (FinnWatch, SACOM and SOMO 2011, 31). Most of the life of electronics workers takes place on factory campuses. Many workers live in dormitories provided by their employer. Factory dormitories are often crowded and provide only little privacy. In 2009 Finnwatch, SACOM and SOMO for example reported that on Foxconn campuses in Shenzhen the dormitory consists of a five storey building with 25 rooms per floor, each shared by eight to ten 10 workers (Finnwatch, SACOM and SOMO 2009, 39). The strict discipline and control of the workshop also enters the dormitory. Ngai Pun argues that "The dormitory labour system ensures that workers spend their off-hours just preparing for another round of production" (Ngai, 23).

Most factory campuses are based within Special Economic Zones (SEZ) that traditionally are located in urban costal areas. A recent trend in China's manufacturing sector is the relocation of production to inland provinces where wage levels are still lower. Foxconn has been relocating parts of its production from costal areas such as Shenzhen to inland provinces (SACOM 2011b, 3). Foxconn workers are forced to relocate to production facilities even farther away from their hometowns (SACOM 2012, 8). Among the new inland campuses are Foxconn production sites in Zhengzhou, Henan province. Because of growing demand new factories are often built and opened in a rush. SACOM reports that the new Zhengzhou factory was operating even before the construction work was finished. For workers this means that basic facilities such as bathrooms or grocery stores are not available (SACOM 2011b, 4). At unfinished factory campuses the environment is dusty on dry days and flooded on rainy days (SACOM 2011b, 4). Likewise Friends of Nature, IPE, and Green Beagle report

\footnotetext{
${ }^{23}$ SOMO. 2011. Time to Bite Into a Fair Apple. Call for Sustainable IT! Join Action Day on May 7th. Retrieved from http://somo.nl/events-en/time-to-bite-into-a-fair-apple-call-for-sustainable-it-ioin-action-day-on-may-7th on October 27, 2011.

${ }^{24} \mathrm{~A}$ video that docments one camaign activitiy can be watched here: http://www.youtube.com/watch?v=kaiXni3h2Ug\&feature=player embedded Retrieved on October 27, 2011.

${ }^{25}$ ChinaWorkers. 2011. "Rotten Apple - Worldwide Protests Against IT Giant's Labour Abuses. Retrieved from http://chinaworker.info/en/content/news/1451/ on October 27, 2011.
} 
that Foxconn's Chengdu campus was built in on 76 days, which created a number of security risks (Friends of Nature, IPE, Green Beagle 2011, 37f).

Labour spaces at Apple's supplier factories are unpleasant and dangerous. The fact that work takes place in centralized factory spaces makes it possible to exert strict control over working hours and behaviour of workers even in their "free" time.

\subsubsection{Labour Times}

Workers are not only underpaid (see section 4.3.2), but also overworked. SOMO in its 2005 investigation of the Foxconn campus in Shenzhen found: "On average, a worker that works 27 days a month and 10-11 hours a day will receive about RMB 1000 a month including all the subsidies and OT [overtime] compensation" (SOMO 2005b, 26). In 2005 1,000 RMB were equivalent to about 100 EUR or 120 USD (SOMO 2005b, 27). Workers at Foxconn complained that during peak season they would not receive a single day off in four months (SOMO 2005b, 15). Another investigation of five Apple supplier factories conducted in 2007 confirmed that overtime between 2.5 and 4 hours per day in addition to the regular working hours of 8 to 9.5 hours were common. In four out of five investigated factories total working hours exceeded 60 weekly hours and at one factory workers even had to work up to 80 hours per week (SOMO 2007a, 22). In 2008 Finnwatch, SACOM and SOMO found similar conditions at Apple's production line at Foxconn's Shenzhen campus. Employees had to work compulsory excessive overtime of up to 120 hours per month, which resulted in a total of 70 hours per week (FinnWatch, SACOM and SOMO 2009, 37).

After the suicides tragedies Finnwatch, SACOM and SOMO conducted a follow up investigation of working conditions at Foxconn. The results show that while at the beginning of 2010 excessive compulsory overtime was still the same as in 2008 , the situation changed after June 2010. From then on workers were granted one day off per week and overtime was reduced from 120 hours to between 75 and 80 hours per month, with still exceeded the legal maximum of 36 hours (FinnWatch, SACOM and SOMO 2011, 29).

Low wage levels and the problem of long working hours are connected to each other: Low wages force workers to work overtime in order to earn enough money to be able to cover their living expenses. A 19-year worker who was producing iPhones at Guanlan, Shenzhen told SACOM: "We do not have much overtime work this month. Our department has 3 shifts a day now. I can only receive a basic salary at CNY 1600 this month. It' $s$ really not enough for a living but I believe the 8-hour shift is just a temporary measure for the low season" (Worker quoted in SACOM 2011a, 9). SACOM's investigation of Foxconn campuses in Shenzhen, Chengdu and Chongquing furthermore showed that workers in Chengdu, where the gap between actual and living wage was highest (see figure 1), also worked most overtime, between 80 and 100 hours per month (SACOM 2011a, 10). In 2012 the FLA found that at the three monitored Foxconn plants in Shenzhen and Chengdu workers during peek season worked more than 60 hours per week. Despite these very long working hours $48 \%$ of the interviewed workers stated that their working hours were reasonable, $33.8 \%$ said that they would like to work more in order to earn more money and $17.7 \%$ reported that their working hours were too long (FLA 2012, 8). In September 2012 SACOM investigated three Foxconn plants in Zhengzhou, Henan Province that are only producing iPhones. The results show that working hours vary strongly depending on Apple's demand. During low season overtime work was as low as 10 hours per month, while during peak season 80-100 hours monthly overtime were common (SACOM 2012, 3). During low season workers thus struggle to earn enough to cover their living expenses, while during high season they are exhausted due to a lack of free time.

Even if overtime work is officially labelled voluntary, low wages often force workers into working excessive overtime. While companies comply with legal minimum wage standards, compliance with regulations for maximum working hours is often insufficient. The fact that minimum wage levels are too low makes compliance relatively easy for companies, while it creates the need for workers to work overtime to earn extra money. The relation between low wages and high overtime rates is a basic structural characteristic of contemporary electronics manufacturing. It allows companies to keep their payroll low at the expense of workers, and at the same time meet high production targets. 


\subsubsection{Type of Work Activity}

Work at Chinese contract manufacturers in the electronics sector in general is characterized by a strong segmentation of the labour process into small, standardized production steps (Lüthje 2008, 67). Low skilled assembly line labour and uniform work procedures therefore dominate work in electronics factories (Lüthje 2008, 73; 2005, 342). Workflows are fragmented and repetitive. One worker told China Labour Watch: "We finish one step in every 7 seconds, which requires us to concentrate and keep working and working. We work faster even than the machines" (Worker quoted by China Labour Watch 2010). Reports from corporate watchdogs show that machines dictates work procedures: SACOM reports that machines at Foxconn's factories have to run 24/7, therefore some workers always have to remain at the shopfloor during meal breaks. These continuous shifts require workers to skip meals. One worker complained:

"The machines in our department are in operation 24/7. If some colleagues go out for dinner, then the workers who stay in the workshop have to take care of 3 machines at the same time. It is hard work but we do not have additional subsidy for that. Workers can only have dinner after the work shift ends. Continuous shift occurs everyday" (Worker quoted in SACOM 2011a, 11).

The work activities workers perform in Apple's supplier factories are monotonous, repetitive and dictated by machines. Their activity can therefore be described as an alienated labour process, as "an activity which is turned against" the worker (Marx 1844/2007, 73). Marx argued that in capitalism the production process turns against the worker because "it is not the worker who employs the conditions of his work, but rather the reverse, the conditions of work employ the worker" (Marx 1867/1990, 548).

Work in Apple's supplier factories is characterized by a separation between mental and manual labour as it is associated with Taylorist production methods. Each step of the labour process is defined and controlled by management, while executed by the worker: "The physical processes of production are now carried out more or less blindly [...] The production units operate like a hand, watched, corrected and controlled by a distant brain" (Braverman 1974/1998, 86).

The computer industry furthermore illustrates the division between manual and mental labour on a global scale. While highly skilled engineers that design computer software and hardware tend to be located in the global North, the physical production and assembly of computer products largely takes place in the global South.

\subsubsection{Control Mechanisms}

Harsh and humiliating management styles are used to control the behaviour of workers at Apple's contract manufacturers. In 2009 Finnwatch, SACOM and SOMO reported about strict disciplinary measures in Apple's production line at Foxconn. No personal belongings were allowed in the factory and procedures of how to start work and leaving the shopfloor were strictly regulated. Workers reported that if asked how they felt they had to shout: "Fine! Very fine! Very, very fine!" Talking, giggling, and crossing legs was forbidden while sitting at the assembly line. Talking might be punished with shopfloor cleaning. Due to time-consuming security checks at toilets and short breaks workers often had to chose between using the bathroom and having lunch (Finnwatch, SACOM and SOMO 2009, 37f).

A follow-up investigation in 2011 showed that disciplinary measures at Foxconn were less strict after the suicides had occurred on the campus, than they were in 2008. However security checks at toilets did still exists and workers still had to collectively reply "Fine! Very fine! Very, very fine!" when asked how they felt (Finnwatch, SACOM and SOMO 2011, 31). At a Foxconn plant in Chengdu new workers for example had to participate in a one to two day long military training which only consisted of lining up and standing (SACOM 2011a, 16). Workers furthermore had to stand up to 14 hours per day. During breaks they were sitting on the floor often without talking to each other because they were too exhausted (SACOM 2011a, 16). If workers made mistakes they had to write confession letters to their supervisors and sometimes even read them loud in front of other workers (SACOM 2011a, 17). Supervi- 
sors were under pressure too. If one of the workers they were supervising made a mistake they had to face punishment themselves (SACOM 2011a, 17). The strict supervision and control mechanisms are a means for factory management to demonstrate its power over workers. It attempts to reduce human behaviour such as talking, eating or using the toilet and to force machine-like qualities onto the workers.

\subsection{Labour Law}

Several laws are in place to regulate work and employment in China including the Chinese Labour Law (1994), the Trade Union Law (1992, 2002), the Labour Contract Law (2007) and the Labour Dispute Mediation and Arbitration Law (2007) (Friedman and Lee 2010, 515). The Labour Contract Law for example entitles workers to a non-fixed term contract after their fixed term contract has been renewed twice and requires employers to pay higher severance payments in case of layoffs (Friedman and Lee 2010, 526). However, a major problem is that these laws often remain unenforced (Friedman and Lee 2010, 515). This is for example the case in regard to maximum hours overtime work. Chinese labour law limits maximum overtime to 36 hours per month (FinnWatch, SACOM and SOMO 2011, 29).

While Apple's contract manufacturers regularly exceed the legal maximum working hours, they mostly comply with minimum wage regulation. However, studies have shown that minimum wages in China are often too low (e.g. SACOM 2011a, 6, 9), which provides an excuse for companies to pay wages that are below the living wage level.

Although a number of labour regulations are in place in China, they often are either too lax (e.g. minimum wages) or not well enforced (e.g. maximum working hours). China furthermore has not ratified the core conventions of the International Labour Organization (ILO) on Forced Labour ${ }^{26}$ and Freedom of Association ${ }^{27}$. Without the ratification of these conventions the legal obligation to protect these fundamental labour rights is weaker. Hong argues that in order to stay competitive in global capitalism the Chinese state "shares the interest with transnational capital to further tap into the reserves of cheap and disciplined labour and to keep down the cost of production" (Hong 2011, 6). Through tax benefits China was successful in attracting foreign enterprises (Hong 2011, 38). The result of these policies is an economic dependency on multinational companies, exports and consumer markets in the global North (Hung 2009, 14). It is therefore important not to underestimate the power multinational corporations have on influencing government policies in China as well as elsewhere.

\subsection{Results of Production}

Apple's products are at the forefront of technological innovation. They are symbols for modern 21 st century lifestyle and progress. The conditions under which these products are produced on the contrary resemble the early days of industrial capitalism. The fact that for example an iPhone costs often twice as much as the average monthly salary of a worker in electronics manufacturing, reveals a deep separation between workers and the fruits of their labour.

Computer technology has the potential to alleviate work, to increase productivity and to reduce the amount of necessary labour time. It entails the potential that especially unqualified, monotonous, repetitive, and mechanical assembly line labour, which reduces workers to extensions of machines without human intellect or creativity, could in the future increasingly be taken over by machines. The way computers are produced today contradicts this potential.

\footnotetext{
${ }^{26}$ Forced Labour Convention (CO29) and the Abolition of Forced Labour Convention (CO105). Source: ILO. 2013. Retrieved from http://www.ilo.org/dyn/normlex/en/f?p=1000:11210:0::NO:11210:P11210_COUNTRY_ID:103404 on May 14, 2013.

${ }^{27}$ Freedom of Organisation and Protection of the Right to Organise Convention (CO87) and the Right to Organise and Collective Bargaining Convention (CO98). Source: ILO. 2013. Retrieved from http://www.ilo.org/dyn/normlex/en/f?p=1000:11210:0::NO:11210:P11210 COUNTRY ID:103404 on May 14,2013
} 
Apple's 2011 marketing campaign praised the design, premium materials and high-quality manufacturing of Apple's products. Apple advertised the iPad as "Amazingly thin and light"28 as a "Technology so advanced, you'll forget it's even there" 29 . According to Apple's ads, "A Mac is as good as it looks. It's made from strong, beautiful materials like aluminium and glass"30: "Take MacBook Air, for example. Its unibody enclosure is machined from a solid block of aluminium. The result is a notebook that is thin and light, looks polished and refined, and feels strong and durable “31. This marketing strategy pictures Apple's products as trendy, clean, sophisticated, elegant and of high quality - a technology that is so advanced that it will expand the capacities of its users and fit their needs so neatly, that they will "forget it's even there".

Apple's marketing slogans present its products as technological marvels without history. They divert attention away from the fact that underpaid Chinese workers are producing these products during 10 to 12 hour shifts at least 6 days a week, in exhausting and repetitive working procedures, while jeopardizing their health. Once displayed on posters, magazines and TV-spots, iPad, MacBook and Co have lost any trace of the conditions under which they were produced.

\subsection{Summary}

Table 2 summarizes working conditions at Apple's contract manufacturers in China.

\begin{tabular}{|c|c|c|}
\hline \multirow[t]{2}{*}{$\begin{array}{l}\text { Productive forces - } \\
\text { Means of production }\end{array}$} & Machines and equipment & $\begin{array}{l}\text { High-tech equipment, e.g. Surface } \\
\text { Mount Technology }\end{array}$ \\
\hline & Resources & $\begin{array}{l}\text { Minerals such as tin, beryllium, gallium, } \\
\text { platinum tantalum, indium, neodymium, } \\
\text { tungsten, palladium, yttrium, gold, and } \\
\text { cobalt; often sourced from conflict areas }\end{array}$ \\
\hline \multirow[t]{3}{*}{$\begin{array}{l}\text { Productive forces - } \\
\text { labour }\end{array}$} & Workforce characteristics & $\begin{array}{l}\text { A majority of young, often female mi- } \\
\text { grant workers }\end{array}$ \\
\hline & $\begin{array}{l}\text { Mental and physical } \\
\text { health }\end{array}$ & $\begin{array}{l}\text { Instances of injuries and deaths due to } \\
\text { unsafe work environments, lack of pro- } \\
\text { tection equipment and insufficient in- } \\
\text { formation of workers } \\
\text { Psychological problems due to social } \\
\text { isolation and exhaustion, instances of } \\
\text { suicides }\end{array}$ \\
\hline & Work experiences & $\begin{array}{l}\text { Workers describe their experiences as } \\
\text { exhausting, humiliating and alienated }\end{array}$ \\
\hline \multirow[t]{3}{*}{$\begin{array}{l}\text { Relations of produc- } \\
\text { tion }\end{array}$} & Labour contract & $\begin{array}{l}\text { Dominance of precarious short term } \\
\text { contracts and agency labour }\end{array}$ \\
\hline & Wages and benefits & $\begin{array}{l}\text { Low wage levels despite compliance } \\
\text { with minimum wage regulation, no living } \\
\text { wage }\end{array}$ \\
\hline & Labour struggles & $\begin{array}{l}\text { Several instances of strikes and pro- } \\
\text { tests but low awareness of and support } \\
\text { from unions }\end{array}$ \\
\hline \multirow[t]{2}{*}{ Production process } & Labour spaces & $\begin{array}{l}\text { Unpleasant and unsafe factory envi- } \\
\text { ronments, crowded factory dormitories, } \\
\text { instances of forced relocation of work- } \\
\text { ers to production facilities in other prov- } \\
\text { inces }\end{array}$ \\
\hline & Labour times & Long working hours of more than 60 \\
\hline
\end{tabular}

${ }^{28}$ Apple. 2011. Retrieved from http://www.apple.com/ipad/ on October 25, 2011.

${ }^{29}$ Apple. 2011. Retrieved from http://www.apple.com/ipad/features/ on October 25, 2011.

${ }^{30}$ Apple. 2011. Retrieved from http://www.apple.com/why-mac/better-hardware/ on October 25, 2011.

${ }^{31}$ Apple. 2011. Retrieved from http://www.apple.com/why-mac/better-hardware/ on October 25, 2011. 


\begin{tabular}{|l|l|l|}
\hline \multirow{2}{*}{} & \multirow{2}{*}{$\begin{array}{l}\text { hours per week during peak seasons. } \\
\text { Working hours highly depend on shifts } \\
\text { in demand }\end{array}$} \\
\cline { 2 - 3 } & Work activity & $\begin{array}{l}\text { High workflow segmentation, uniform } \\
\text { and repetitive production steps, separa- } \\
\text { tion of manual and mental work }\end{array}$ \\
\cline { 2 - 3 } & Control mechanism & $\begin{array}{l}\text { Harsh, military management styles and } \\
\text { harassment of workers }\end{array}$ \\
\hline Results of production & Labour product & $\begin{array}{l}\text { High-tech computer products and con- } \\
\text { sumer electronics: computers, } \\
\text { mp3players, mobile phones, tablet } \\
\text { computers }\end{array}$ \\
\hline & Labour law & $\begin{array}{l}\text { Insufficient enforcement of labour laws, } \\
\text { low minimum wages and missing ratifi- } \\
\text { cation of ILO core conventions on } \\
\text { forced labour and freedom of associa- } \\
\text { tion }\end{array}$ \\
\hline
\end{tabular}

Table 2: Working conditions at Apple's contract manufacturers

The results of the analysis provided here show that labour rights are systematically undermined in the factories of Apple's contract manufactures. The next section discusses Apple's response to the bad working conditions in the factories of its Chinese contract manufacturers.

\section{Defending the Myth: Apple's Response to Labour Right Violations}

Apple's response to labour right violations in its supply chain is very reactive. The company published its first Supplier Responsibility document as a reaction to ongoing criticism of its supply chain management. It starts with the following sentence: "In the summer of 2006, we were concerned by reports in the press alleging poor working and living conditions at one of our iPod final assembly suppliers in China“ (Apple 2006, 1). Since then Apple published one Supplier Responsibility Report per year. These reports promise that Apple "is committed to the highest standard of social responsibility in everything we do. We are dedicated to ensuring that working conditions are safe, the environment is protected, and employees are treated with respect and dignity wherever Apple products are made" (Apple 2006, 4).

Based on Teun A. van Dijk's (2006) concept of the ideological square I in the following analyse the arguments Apple puts forward in its Supplier Responsibility Reports in order to demonstrate its efforts to improve working conditions. The ideological square identifies four possible ideological strategies that describe different ways of how the relation between ingroups and out-groups, between "us" and "them" is represented in talk or text (Van Dijk 2006, 397). These strategies are: "Emphasize Our good things", "Emphasize Their bad things", "De-emphasize Our bad things", "De-emphasize Their good things" (Van Dijk 2006, 396). Three of these strategies are present in Apple's response to watchdog criticism: Apple is deemphasizing its own wrongdoings by downplaying the extent of the problem of labour rights violations (see section 5.1), while at the same time emphasizing its achievements by using a rhetoric of continuous improvement (see section 5.2). The company furthermore emphasizes the wrongdoings of others by blaming Chinese managers and workers for the persistence of bad working conditions (see section 5.3).

\subsection{De-Emphasize Our Bad Things: Downplaying the Extent of the Problem}

The strategy that is most dominant in Apple's response to labour rights allegations is to deemphasize the extent of the problem. While watchdog reports document the persistence of serious labour rights issues (see section 4), Apple's Supplier Responsibility reports suggests that the problems are much less severe. 
In its reports Apple defines "core violations" of its Code of Conduct, which require immediate improvements. These include physical abuse, child labour, forced labour, false audits, severe threats to worker safety and intimidation of workers that are interviewed during audits (Apple 2007, 7; Apple 2012, 10). Apple stresses that it considers core violations "as contrary to the core principles underlying Apple's Supplier Code of Conduct and require immediate corrective actions" (Apple 2007, 7).

Apparently it is not a "core principle" of Apple's business practices that workers who are producing the products that are the basis for Apple's profits, are paid for their work and have reasonable working hours. As neither underpayment nor overwork are considered a core violation, no immediate solution needs to be found if these problems occur. Apple thus defacto tolerates, that workers receive wages that hardly suffice for paying basic living expenses, while working up to a point of complete exhaustion. By not regarding these issues as core violations Apple downplays how severe these problems are for workers.

Apart from this general downplaying of the problem of low wages and long working hours Apple's Supplier Responsibility reports furthermore hide the full extent of labour rights violations behind statistics and numbers and describe the problem as the result of minor shortcomings while ignoring structural causes:

- Fetishism of statistics: Throughout Apple's Supplier Responsibility reports hardly any descriptions about how working conditions in its supplier factories actually look like can be found. Apple only provides statistical data that actually tells little about the daily work and life experiences of workers. According to Apple's own audits, the non-compliance rate in regard to payment of at least minimum wages and transparent wage calculations was $46 \%$ in $2007,41 \%$ in 2008, 35\% in 2009, 30\% in 2010, 31\% in 2011 and $28 \%$ in 2012 (Apple 2007-2012). Although these figures show an improvement, it still means that a large number of workers in Apple's supplier factories are paid below the legal minimum. Considering that the even the legal minimum is often below a living wage, these numbers are even more troubling.

Apple's figures on working hours give a similar picture. Non-compliance with a maximum 60 hours per week was $82 \%$ in $2007,59 \%$ in $2008,54 \%$ in $2009,68 \%$ in $2010,62 \%$ in 2011 before it suddenly dropped to $8 \%$ in 2012 (Apple 2007-2012). As an explanation for this sudden decrease of non-compliance in regard to weekly working hours Apple sates: "In 2012, we changed our measurement on working hours to one that is more meaningful and effective" (Apple 2012, 29). This explanation suggests that the sudden decrease in working hours stems from changes in measurement rather than actual changes in working conditions. Furthermore it is problematic that Apple considers a 60-hour working week as desirable. In fact, a 60-hour working week violates Chinese labour law. In China a regular working week must not exceed 44 hours. In addition maximum overtime according to the law is 9 hours per week. This means that including overtime, Chinese labour law limits working hours to 53 hours per week ${ }^{32}$. By calculating compliance with maximum working hours based on a 60-hour working week, which exceeds the legal maximum, Apple's audits misrepresent the extent to which workers are working excessive overtime. Without any descriptions of the work realities of workers the statistics Apple presents furthermore remain abstract and therefore hide how severe low wages, long working hours or the lack of health protection can be for the lives of individual workers and their families.

- Ignoring root causes: Apple has a strong business interests in keeping production costs low. In a 2012 financial statement Apple highlights that it has to deal with strong prize competition: "The markets for the Company's products and services are highly competitive and the Company is confronted by aggressive competition in all areas of its business. [...] The Company's competitors who sell mobile devices and personal computers based on other operating systems have aggressively cut prices and lowered their product margins to gain or maintain market share" (Apple SEC-Filings, 10-k form 2012, 6).

This structural contradiction between Apple's need to reduce labour costs in order to stay competitive, and low wages, low safety standards and long working hours is not addressed

\footnotetext{
${ }^{32}$ China.org. Labour Law of the People's Republic of China. Retrieved from http://www.china.org.cn/living in china/abc/2009-07/15/content 18140508.htm on May 15, 2013.
}

CC: Creative Commons License, 2013. 
in Apple's Supplier Responsibility reports. Furthermore Apple's response to the suicide tragedies ignores connections between bad working and living conditions and the suicide tragedies. In its 2010 report Apple highlighted that it is "disturbed and deeply saddened to learn that factory workers were taking their own lives at the Shenzhen facility of Foxconn" (Apple 2010, 18). Apple stressed that as a reaction to the suicides it launched "an international search for the most knowledgeable suicide prevention specialists - particularly those with experience in China - and asked them to advise Apple and Foxconn" (Apple 2010, 18). A team of suicide prevention experts was formed which conducted a questionnaire survey among 1,000 Foxconn workers, face to face interviews with workers and mangers, investigated each suicide individually and evaluated Foxconn's response to the suicides (Apple 2010, 18). The result of this evaluation was that Foxonn's reaction to the suicides was ideal: "Most important, the investigation found that Foxconn's response had definitely saved lives" (Apple 2010, 19). Suggestions for further improvement were only made regarding the training of hotline and care centre stuff (Apple 2010, 19).

Both the measures taken by Apple and the improvement suggestions made by the "most knowledgeable suicide prevention specialists" seem rather limited. They do not include any improvement of working conditions, which according to different labour rights groups had been bad for many years (SOMO 2005b; FinnWatch, SACOM and SOMO 2009; FinnWatch, SACOM and SOMO 2011; SACOM 2011a,b, 2012, 2013). The anti-suicide team's findings suggest that the suicides had nothing to do with working conditions at Foxconn. A study conducted by China Labour Watch (2010) tells a different story. On May 17, 2010 China Labour Watch asked 25 Foxconn workers about what they believed were the reason for the suicides of Foxconn workers. 17 said that high pressure at work was the main reason. Five workers argued that a lacking sense of community at Foxconn has led to the suicides, as even workers that were living in the same room would not know each other. Three workers doubted that the reasons for the deaths actually were suicides (China Labour Watch 2010).

Apple, by failing to discuss the connection between the suicides of workers and problems such as low wages, excessive working hours, humiliation, work pressure, social isolation etc, de-emphasizes the extent to which workers are suffering from bad working conditions.

\subsection{Emphasize Our Good Things: A Rhetoric of Continuous Improvement}

Apple's Supplier Responsibility Reports put forward a story of continuous improvement. They are officially labelled as "Progress Report". In the 2009 report Apple for example states: "In general, annual audits of final assembly manufacturers show continued performance improvements and better working conditions" (Apple 2009, 15). The 2007 report states: "By aggressively auditing our suppliers and pursuing corrective actions, Apple has improved living and working conditions for tens of thousands of employees in our supply chain" (Apple_SR 2007, 14). Similarly in the 2010 report Apple highlights "Our repeat audits showed continued performance improvements and better working conditions" (Apple_SR 2010, 15).

This rhetoric of improvement detracts from the fact that working conditions are bad, as independent research shows (see section 4). Evidence for these alleged improvements is provided by reference to statistics form Apple's own audits. Apple claims that treatment of workers is "fair" in more than $90 \%$ of all monitored factories (Apple 2007-2012). By pointing at improvements and stressing that workers are treated in a fair way in the majority of cases Apple's is putting forward a positive image about working conditions in its supply chain.

This focus on good things also characterized Steve Job's response to the suicide at the Foxconn factory campus. He stated that "Foxconn is not a sweatshop". "You go in this place and it's a factory but, my gosh, they've got restaurants and movie theatres and hospitals and swimming pools. For a factory, it's pretty nice" (Jobs 2010). Considering the descriptions of unacceptable working realities at Foxconn campuses provided in watchdog reports (see section 4) as well as the low compliance rates according to Apple's own audits (see section 5.1), this statement sounds overly euphemistic. The cynical character of Job's statement becomes evident when it is compared to a quote from a worker that appeared on a blog after the $12^{\text {th }}$ suicide at Foxconn: "Perhaps for the Foxconn employees and employees like us - we who are called nongmingong, rural migrant workers, in China - the use of death is simply to tes- 
tify that we were ever alive at all, and that while we lived, we had only despair" (Foxconn worker quoted in Chan and Ngai 2010).

\subsection{Emphasizing Their Bad Things: Blaming Others}

Apple's Supplier Responsibility Reports frame the problem of labour rights violation in a way that puts the entire blame on Chinese contract manufacturers. This rhetoric suggests that the existence of bad working conditions is solely due to a lack of management skills of suppliers, and has nothing to do with Apple. Apple presents itself as a benevolent saviour that is bringing knowledge to developing countries. According to its Supplier Responsibility reports Apple seems to believe that its only responsibility consist in telling suppliers what they have to do. In the 2009 report Apple for example highlighted: "Apple's approach to supplier responsibility extends beyond monitoring compliance with our Code. We help our suppliers meet Apple's expectations by supporting their efforts to provide training in workers' rights and occupational health and safety" (Apple 2009, 3). At no point Apple mentions how much money it is paying for the production of its products in these supplier factories and whether this amount is enough for ensuring adequate working conditions. By blaming its suppliers Apple detracts attention away from the fact that these workers are in fact working for Apple and Apple therefore is responsible for ensuring that at least their working environment is save, that they receive a wage which allows them to pay their living expenses and that their working hours do not extend beyond certain limits. Blaming contract manufacturers detracts from the fact that Apple keeps almost $60 \%$ of the sales prize of an iPhone as a profit while spending less than $2 \%$ for labour cost of final assembly in China (Kraemer, Linden and Dedrick 2011, 5).

Apple's response to labour rights allegations follows certain ideological patterns: It downplays the severity of the problem of low wages and long working hours, avoids descriptions of actual work and life realities of workers by only referring to statistics and numbers, and ignores structural causes of the labour rights problem (de-emphasizing Apple's wrongdoings). The company stresses that the situation is continuously improving although independent research shows that problems persist (emphasizing Apple's achievements); and describes suppliers, rather than Apple itself, as the ones actually responsible for labour rights violations (emphasizing the wrongdoing of others).

Apple's rhetoric tends to downplay the scope of labour rights violations, mystifies their relation to Apple's business interest in cheap labour and attempts to deny the company's responsibility for bad working conditions in its supply chain. It defends Apple's business practices by detracting attention away from structural contradictions and social irresponsibilities that are connected to them.

\section{Conclusion}

In this paper I first showed that neoliberal globalization, the transformation of international production networks together with Chinese policy reforms allowed multinational corporations to gain access to millions of Chinese workers (section 1). Apple is an economically successful and admired company. Most of its profits are based on hardware products such as iPhone, iPad, iPod, Laptops and Desktop Computers. While for Apple these products mean success, for the workers in the factories of Apple's contract manufacturers they mean misery (section 3). Their labour and lives often remain invisible, hidden behind the shiny surface of modern high-tech products. In order to shed light on this dark side of computer products I constructed a systematic model of working conditions based on the circuit of capital as it has been described by Karl Marx. This model starts with the productive forces including means of production one hand and the labour power of workers on the other hand. It then addresses the relations of production as they are expressed in a particular relation between capital and labour that determines wages, labour contracts and is subject to struggles. In order to produce a commodity, labour and means of production enter the production processes, which is shaped by labour spaces, labour times, the type of work activity and control mechanisms. The model also includes the produced commodity and the question how it relates back to the worker. Finally, it includes labour legislation and its impact on working conditions (section 2) 
This model of working conditions can be applied to study and compare working conditions in a variety of different industries. In this paper I used it for describing the "Foxconned labour" of workers in Chinese workshops of Foxconn, Wintek, Pegatron and others where Apple's products are assembled. The results show that workers are partly dealing with high-tech equipment when assembling parts of computers that often contain conflict minerals. The relation between capital and labour is characterized by low wages, precarious contracts and occasionally contested by labour struggles. The production process is shaped by work and live in the factory, long working hours, repetitive and monotonous manual work and strict control. Mostly young migrant workers are risking their health and safety and experience of alienation, exhaustion and despair. They are producing high-tech computer products that they are unlikely to ever own themselves. Labour laws often remain unenforced and therefore offer little protection for workers.

Finally, in discussing Apple's response to the problem of bad working conditions I identified three ideological patterns that deflect attention away from the structural irresponsibility of Apple's business practices by using a rhetoric of improvement, hiding behind statistics, blaming others, looking at symptoms rather than root cause, or downplaying the problems (section 5).

The example of Apple illustrates that there is a wide gap between the qualities of the products workers are producing and the conditions under which they are produced. While working conditions resemble the early days of industrial capitalism, the produced-high tech computer products build the foundation for $21^{\text {st }}$ century knowledge work. Apple thus represents progress and regression at the same time. Karl Marx described this contradictory quality of capitalism when he stressed:

"It is true that labour produces for the rich wonderful things-but for the worker it produces privation. It produces palaces - but for the worker hovels. It produces beauty - but for the worker, deformity. It replaces labour by machines - but some of the workers it throws back to a barbarous type of labour, and the other workers it turns into machines. It produces intelligence - but for the worker idiocy, cretinism" (Marx 1844/2007, 71).

The labour performed in Chinese workshops produces profits for Apple and marvellous computer products for those who can afford them, while for workers it produces monotony and despair.

However, ICTs at the same time do not only mean misery for workers, but can also be a means of empowerment: Jack Qiu (2009) points out that the Internet and wireless communication is increasingly available to members of the Chinese working class. He stresses that rather than describing Chinese low-income groups as "information have-nots", they should be regarded as "information have-less" as they increasingly have access to the Internet and to inexpensive "working-class ICTs" that are produced for the Chinese market (Qiu 2009, 3f). These "working class ICTs" such as mobile phones or computers can be used "in order for the concerns of the have-less to reach across social divisions and have a general impact on society" (Qiu 2009, 243). Information about labour rights violations or protest can sometimes reach the mass media via online forums or self-made videos (Qiu 2009, 243). Qiu highlights that in the context of the spread of working-class ICTs there are "important instances of working-class cultural expression and political empowerment using tools as blogs, poetry, and mobile phones, which serve as the substance of new class dynamics in the twenty-first century" (Qiu 2009, 232). ICTs can thus be used as tools to support struggles for worker rights.

Although this paper focuses on Apple it is important to be aware that similar working conditions as described here can be found throughout the electronics industry as well as other manufacturing sectors such as garment or toy production. Apple thus is more than a "bad apple". It is an example of structures of inequality and exploitation that characterize global capitalism. In order to confront these structural problems it is not enough to rely on corporate self-regulation, Codes of Conduct and promises of Corporate Social Responsibility. It is important to recognize that cheap production costs that result in bad working conditions are an important competitive advantage for companies. Raising wages, reducing working hours, improving health and safety protection etc would increase expenditures and thus negatively 
impact profit goals. Without international laws and regulations that force companies to meet certain standards it is unlikely that working conditions will improve.

However desirable stricter regulation might be, rather than waiting for top-down changes to occur, workers need to organize and struggle for their rights. In times of international value chains increasing pressure on governments and corporations requires international solidarity.

Pointing at the need to study the industrial labour of those who produce computer technologies in factories does not mean to idealize the working life of engineers, designers or media professionals. It rather seems important to highlight connections between these different forms of labour: what unites them is not only that they all, in different ways, deal with new information and communication technologies, but also that they are all subject to exploitation, high work pressure and often precariousness. Rather than using concepts such as "immaterial labour" (Hardt and Negri 2004) that reinforce the separation of manual and mental work it seems more useful to extend concepts such as knowledge work or digital labour to include the manual work of those who are producing computer technologies, electronic equipment and media technologies. I therefore agree with Hong who argues that "in the context of information and communications, we actually need to extend the concept of the "knowledge worker' to include manual and industrial workers who are also essential to this industry" (Hong 2011, 11). Digital labour likewise includes both the mental and manual labour of workers who use ICTs and digital technologies as means of production and of those who produce and dispose them. Such extended notions can provide a conceptual framework for analysing the international division of digital labour. Broad understandings of digital labour can furthermore be a starting point for building connections and moments of solidarity along the global value chain of computer technologies from mineral miners and production workers to call centre agents, software engineers, and the labour of unpaid prosumers, back to waste workers in electronics dumping grounds.

\section{References}

Apple. 2006-2012. Supplier Responsibility. Progress Report. Accessed May 2013. http://www.apple.com/supplierresponsibility/reports.html

Apple SEC-Filings. 10-k forms 1994-2012. In Edgar Database. Accessed May 20, 2013. http://www.sec.gov/cgi-bin/browse-edgar?action=getcompany \&CIK=0000320193\&type $=10$ k\&dateb=\&owner=exclude\&count $=40$

Braverman, Harry. 1974/1998. Labor and Monopoly Capital: The Degradation of Work in the Twentieth Century. New York: Monthly Review Press.

Bread for All and SACOM. 2008. High Tech - No Rights. Accessed May 13, 2013. http://sacom.hk/wpcontent/uploads/2008/07/report-high-tech-no-rights-may2008.pdf

Chan, Jenny and Pun Ngai. 2010. Suicide as Protest for the New Generation of Chinese Migrant Workers: Foxconn, Global Capital, and the State. The Asia-Pacific Journal. http://japanfocus.org/Jenny-Chan $/ 3408$

China Labour Watch. 2010. "We are extremely tired, with tremendous pressure" A follow-up investigation of Foxconn. Accessed October 20, 2011 http://www.chinalaborwatch.org/pro/proshow-100.html

Danwatch. 2011. What a Waste. Accessed May 16, 2013. http://makeitfair.org/en/thefacts/reports/reports/2011

Dyer-Whiteford, Nick. 2014 (forthcoming). The global worker and the digital front. In Critique, Social Media and the Information Society, edited by Christian Fuchs and Marisol Sandoval. New York: Routledge.

Finnwatch. 2007. Connecting Components, Dividing Communities. Accessed May 14, 2013. http://makeitfair.org/en/the-facts/reports/2007-2009/reports-from-2009/Connecting-ComponentsDividing-Communities.pdf/at download/file

Finnwatch, SACOM and SOMO. 2009. Playing With Labour Rights. Accessed October 19, 2011.

http://makeitfair.org/the-facts/reports/playing-with-labour-rights/at download/file

FinnWwatch, SACOM and SOMO. 2011. Game Console and Music Player Production in China. Accessed October 19, 2011. http://makeitfair.org/the-facts/reports/game-console-and-music-playerproduction-in-china

FLA. 2012. Independent Investigation of Apple Supplier, Foxconn. Accessed April 10, 2012. http://www.fairlabor.org/sites/default/files/documents/reports/foxconn investigation report.pdf 
Free the Slaves. 2011. The Congo Report. Accessed May 13, 2013.

http://www.freetheslaves.net/Document.Doc?id=243

Friedman, Eli and Ching Kwan Lee. 2010. Remaking the world of Chinese labour: A 30-year retrospective. British Journal of Industrial Relations 48 (3): 507-533.

Friends of Nature, IPE, Green Beagle. 2011. The Other Side of Apple II. Accessed October 23, 2011. http://www.ipe.org.cn/En/about/notice de 1.aspx?id=10281

Friends of the Earth. 2012. Mining for Smartphones. The True Cost of Tin. Accessed April 12, 2013. http://www.foe.co.uk/resource/reports/tin mining.pdf

Fröbel, Folker, Jürgen Heinrichs and Otto Kreye. 1981. The New International Division of Labour. Cambridge: Cambridge University Press.

Hardt, Michael and Antonio Negri. 2004. Multitude. London: Hamish Hamilton

Harvey, David. 2005. A Brief History of Neoliberalism. Oxford: Oxford University Press.

Harvey, David. 2006. Spaces of Global Capitalism. London: Verso.

Hong, Yu. 2011. Labor, Class Formation, and China's Informationized Policy and Economic Development. Lanham, MD: Rowman \& Littlefield.

Hung, Ho-Fu. 2009. America's head servant? THe PRC's dilemma in the global crisis. New Left Review 60: 5-25.

ICO, FinnWatch and ECA. 2005. Day and Night at the Factory. Accessed October 19, 2011. http://www.corporatejustice.org//MG/pdf/en kiina-raportti.pdf

Jobs, Steve. 2010. Interview at the 2010 D8 conference. Accessed May 10, 2013. http://www.youtube.com/watch?v=KEQEV6r2l2c

Kramer, Kenneth L, Greg Linden and Jason Dedrick. 2011. Capturing Value in Global Networks: Apple's iPad and iPhone. Accessed May 14, 2013. http://pcic.merage.uci.edu/papers/2011/Value iPad iPhone.pdf

Linzmayer, Owen W. 2004. Apple Confidential 2.0: The Definitive History of the World's Most Colourful Company. San Francisco: No Starch Press.

Lüthje, Boy. 2006. The Changing Map of Global Electronics: networks of Mass Production in the New Economy. In Challenging the Chip. Labour Rights and Environmental Justice in the Global Electronics Industry, edited by Ted Smith, David A. Sonnenfeld and David Naguib Pellow, 17-30. Philadelphia: Temple University Press.

Lüthje, Boy. 2008. Arbeitspolitik in der Chinesischen IT Industrie - neue Perspektiven in der Diskussion um internationale Arbeitsstandards. Accessed May 13, 2013. http://www.boeckler.de/pdf fof/S-2007-14-1-1.pdf

Lüthje, Boy. 2012. Interview. Accessed May 20, 2013. http://www.cultofmac.com/153784/heres-whatworking-conditions-at-chinese-electronics-plants-are-really-like-exclusive-interview/

Marx, Karl. 1844/2007. Economic Philosophic Manuscripts. Mineola, New York: Dover Publications.

Marx, Karl. 1867/1992. Capital Vol I. London: Penguin.

Marx Karl 1885/1992. Capital Vol II. London: Penguin

Maxwell Richard and Toby Miller. 2012. Greening the Media. Oxford: Oxford University Press.

McGuigan, Jim 2005. Neoliberalism, Cultural and Policy. International Journal of Cultural Policy 11 (3): 229-241.

McKinsey \& Company. 2012. Manufacturing in the Future: The Next Era of Global Growth and Innovation. Accessed May 18, 2013. http://www.mckinsey.com/insights/manufacturing/the future of manufacturing

Mosco, Vincent. 2004. The Digital Sublime. Cambridge: The MIT Press.

Munck, Ronaldo. 2002. Globalisation and Labour. New York: Palgrave.

Ngai, Pun. Apple's Dream and Foxconn's Nightmare. Accessed May 15, 2013. http://burawoy.berkeley.edu/Public\%20Sociology,\%20Live/Pun\%20Ngai/PunNgai.Suicide\%20or\%2 OMuder.pdf

Plank, Leonhard and Cornelia Staritz. 2013. Precarious Upgrading' in Electronics Global Production Networks in Central and Eastern Europe: The Cases of Hungary and Romania. Accessed May 18, $2013 \mathrm{http}: / / \mathrm{www}$.capturingthegains.org/pdf/ctg-wp-2013-31.pdf

Qiu, Jack. 2009. Working-Class Network Society. Cambridge: MIT Press.

Reputation Institute 2012. Is CSR Dead or Just Mismanaged. Accessed February 14, 2013. http://www.reputationinstitute.com/thought-leadership/complimentary-reports-2012

SACOM. 2010. Apple Owes Workers and Public a Response over the Poisoning. Accessed October 16, 2011. http://sacom.hk/wp-content/uploads/2010/05/apple-owes-workers-and-public-a-responseover-the-poisonings.pdf 
SACOM. 2011a. Foxconn and Apple Fail to Fulfil Promises: Predicaments of Workers after the Suicides. Accessed October 20, 2011. http://sacom.hk/wp-content/uploads/2011/05/2011-0506 foxconn-and-apple-fail-to-fulfill-promises1.pdf

SACOM. 2011b. iSlave behind the iPhone. Foxconn Workers in Central China. Accessed October 20, 2011. http://sacom.hk/wp-content/uploads/2011/09/20110924-islave-behind-the-iphone.pdf

SACOM. 2012. New iPhone, Old Abuses. Have Working Conditions at Foxconn in China Improved? Accessed May 13, 2013. http://www.waronwant.org/attachments/SACOM\%20$\% 20 \% 20$ New $\% 20$ iPhone, $\% 20$ Old\%20Abuses $\% 20-\% 2020-09-12$.pdf

SACOM. 2013. Apple Fails in Its Responsibility to Monitor Suppliers. Accessed May 13, 2013. http://makeitfair.org/en/the-facts/reports/apple-fails-in-its-responsibility-to-monitorsuppliers/at download/file

Smith, John. 2012. Outsourcing, Financialization and the Crisis. International Journal of Management Concepts and Philosophy 6 (1/2): 19-44.

SOMO. 2005a. CSR Issues in the ICT Hardware Manufacturing Sector. By Irene Schipper and Esther de Haan. Accessed October 17, 2011 http://somo.nl/publications-nl/Publication 476nl/at download/fullfile

SOMO. 2005b. ICT Hardware Sector in China and Corporate Social Responsibility Issues. By Monina Wong. Accessed October 16, 2011. http://somo.nl/publicationsen/Publication 624/at download/fullfile

SOMO. 2007a. Apple. CSR Company Profile. By Michiel van Dijk and Irene Schipper. Accessed October 17, 2011. http://somo.nl/publications-en/Publication 1963/at download/fullfile

SOMO. 2007b. Capacitating Electronics. The Corrosive Effects of Platinum and Palladium Mining on Labour Rights and Communities. Accessed May 13, 2013. http://makeitfair.org/en/thefacts/reports/2007-2009/reports-from-2009/Capacitating-Electronics-november2007.pdf/at download/file

SOMO 2011. Unheard Voices. Accessed May 13, 2013. http://makeitfair.org/en/thefacts/reports/unheard-voices/at download/file

Su, Yihui. 2011. Student Workers in the Foxconn Empire. The Commodification of Education and Labour in China. Journal of Workplace Rights 15 (3-4): 341-362.

Swedwatch. 2007. Powering the Mobile World. Accessed May 13, 2013. http://makeitfair.org/en/thefacts/reports/2007-2009/reports-from-2009/Powering-the-Mobile-World-Swedwatch-November2007.pdf/at download/file

Swedwatch, SACOM and SOMO. 2008. Silenced to Deliver. Accessed May 13, 2013 http://makeitfair.org/en/the-facts/reports/2007-2009/reports-from-2009/silenced-todeliver/at download/file

The New Generation Migrant Workers Concern Programme. 2013. The Report on Foxconn Trade Union Research. Accessed May 13, 2013. https://www.dropbox.com/s/qzwo85nzly5u8wh/2013.05.01\%20\%20English\%20excerpt\%20on\%20Foxconn\%20union\%20research\%20report.pdf

WTEC. 1997. Electronics Manufacturing in the Pacific Rim. Accessed May 18, 2013. http://www.wtec.org/loyola/pdf/em.pdf

Zhao, Yuezhi and Robert Duffy. 2008. Short-Circuited? The Communication and Labor in China," In Knowledge Workers in the Information Society, edited by Catherine McKercher and Vincent Mosco, 229-248. Lanham: Lexington Books

\section{About the Author}

Marisol Sandoval is a Lecturer in Culture, Policy and Management at City University London. Her current research interests include alternative media, critical political economy of media and communication, the global division of labour in the culture industry, and Corporate Social (Ir)Responsibility. Marisol has co-edited the collected volumes "Internet and Surveillance. The Challenges of Web 2.0 and Social Media" (Routledge 2012) and "Critique, Social Media and the Information Society" (Routledge 2013). 